\title{
A STUDY OF THE PSYCHIC TERM vóం IN THE GREEK LYRIC POETS (EXCLUDING PINDAR AND BACCHYLIDES)
}

\author{
In memoriam $R$. D. Sullivan
}

The psychic term vós in the lyric poets, as in Homer, Hesiod, and the Homeric Hymns, seems best described as a faculty capable of a number of psychological activities'. It functions as a seat of disposition, temperament, and character. Moral traits in particular are associated with it. Noos, in others, especially reflects their true attitudes and thoughts. In this psychic entity an individual finds himself most authentically expressed.

\section{INTRODUCTION}

The psychological term vóos occupies a position of importance in early Greek literature. It occurs in 116 passages of Homer and the Homeric Hymns; it is found in 26 passages of Hesiod '. Noos is mentioned as well in a large number of passages in the Greek lyric poets. The present article will analyse these instances (excluding those in Pindar and Bacchylides, which will be treated separately). It will focus upon the range of meaning of vós and the ways in which a person related to this psychic entity. Similarities with and differences from the usage of voos found in Homer, Hesiod, and the Homeric Hymns will be discussed. Distinctive features of voos that appear in this lyric poetry will be highlighted.

Three aspects of this lyric poetry will be kept in mind in the analysis of voos to follow. First, it is fragmentary in nature. This feature makes generalisations drawn about vós, of necessity, tentative, even though they may be valid for the evidence we do possess. Second, it is composed in different metres. The choice of voos rather than another psy-

1 On voos in these authors see S. M. Darcus, «A Person's Relation to voos in Homer, Hesiod, and the Greek Lyric Poets", Glotta 58, 1980, pp. 33-44; S. D. Sullivan, "The Psychic Term Noos in Homer and the Homeric Hymns" (forthcoming) and "The Psychic Term Noos in the Poetry of Hesiod" (forthcoming) with bibliography on other studies of vós in these authors. 
chological term may well have been influenced by demands of metre. Once again this aspect will bear upon the generalisations we can draw about voos. Third, these authors write in the language of poetry. The scope of meaning and usage of voos may have been far different in the spoken language of their day and, then again, it may not. In this paper, therefore, we can validly speak of the range of meaning of voos only within the specific context of the poems that have survived.

Before treating voos in the lyric poets, we will offer a brief summary of its usage in Homer, Hesiod, and the Homeric Hymns. This summary will allow us to clarify different features of voos that may appear in these poets. The epic language, used by Homer and Hesiod, was one with a long history. These poets drew on a rich resevoir of poetry that had been repeated by bards for centuries. This poetry was formulaic in structure. It was written in a specific metre, dactylic hexameter. Both these features had a marked influence on the manner in which different psychic terms appeared within it. One point is particularly important: the psychological term vóos, like other such terms, had been a part of the Greek language for a very long time before it appeared in the lyric poetry we shall examine.

In Homer, Hesiod, and the Homeric Hymns, voos has certain prominent features. It occurs only in the singular but in all four cases. Unlike other psychic entities, vóos in this early poetry shows no traces of a physical origin. When it is located, it is usually placed in the chest region ( $\sigma \tau \eta \dot{\theta} \varepsilon a)$, but once it is found in $\theta u \mu \delta \varsigma$ (Od. XIV 490) and, another time, in фpéves (Il. XVIII 419).

As with other psychic entities, the roles of agent and function are not sharply delineated in mentions of voos. It can be the agent that thinks, feels, and wills and also the thoughts, feelings, and plans that are formed. It seems most appropriately described in this early literature as a "faculty capable of a range of psychological activity". This psychological activity is complex in nature, including aspects commonly separated in modern terminology, namely those that are intellectual, emotional, and volitional. Such aspects are still fused in the language of Homer and Hesiod. Although one or another of these aspects may appear to be prominent in certain passages, all may be present in any occurrence of vós. In the case of vóos intellectual activity is prominent. Often it appears to be a form of «inner vision" in which vós grasps the meaning or significance of a situation ${ }^{2}$. But a wider range of intellectual

2 See, e.g., Il. X 226, XV 461, XXIII 149; Od. VI 320, X 494, XIII 255; Hes., Theog. 537, W. \& D. 373. For a discussion of this activity of voos see Sullivan (note 1) with bibliography. 
function seems also associated with vóos: pondering, devising, or deli-

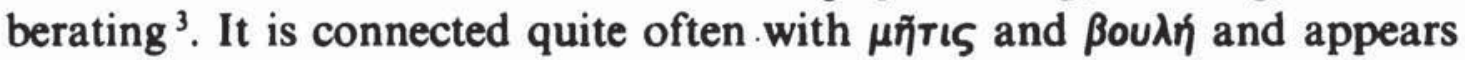
with the verb $\beta o u \lambda \varepsilon u \omega^{4}$. Such passages suggest that voos did not simply «see» within but may have considered alternatives and choices. Since it is unlikely that mental activities were sharply delineated in the time of Homer and before, it is not surprising to find a wide range of intellectual activity associated with this psychic term.

Sometimes this activity of voos can be described as particularly emotional ${ }^{5}$. But this aspect of vós does not appear to be a prominent one. Its volitional aspect, on the other hand, seems often important. This is especially true in the case of Zeus' voos, which expresses his plans, wishes, and will ${ }^{6}$.

Within the person voos has a significant role. It can be an active agent that strongly affects his behaviour ${ }^{7}$. It can also be acted upon either by the person himself or by outside forces or agents ${ }^{8}$. In several instances it appears as an entity «known» or «recognised» by others. As such, it seems to function prominently within a person as an entity revealing his true nature.

Nóos displays various qualities in the person. In some cases it suggests permanent aspects of someone. It can have a positive nature and be, for example, 'fearless', 'well-fitted', 'god-fearing', 'noble', or 'great'. Or, it can be negative: 'evil', 'unbending', 'rather hasty', or 'shameless' ${ }^{10}$. But voos also changes. Odysseus says that it does so with the "day" (Od. XVIII 136). Hesiod too relates a particular "day" to a relationship a person has with vós: someone born on the twentieth day is "cautious in respect to vós" (W. \& $D$. 793). Nós also appears to improve with age (Il. XXIII 590, 604). In other passages as well Homer speaks of vóos as being different in different situations ". Hesiod likewise describes vós in this way. That of Zeus, for example, is "variable» $(W . \& D .483)$. Both authors also mention outside forces and agents

${ }^{3}$ See, e.g., Il. I 132, I 363; Od. II 236, XVI 197.

4 See, e.g., Il. VII 447, XV 509; Od. V 23, XIII 305, XIX 326. 122.

see, e.g., Il. IX 554, XIV 217; Od. VIII 78; $H$. XIX 41, XXVII 27; Hes., Theog.

6 See, e.g., Il. VIII 143, XV 242; Od. V 103, XXIV 164; H. Her. 10; Hes., Theog. $1002, W . \& D .105,483$.

7 See, e.g., Il. XIV 162, XV 80; Od. II 92, XXIV 474; H. Her. 396.

${ }^{8} \mathrm{See}$, e.g., Il. XIV 217, XV 52; Od. II 124, XIX 42; H. Cer. 37; Hes., Theog. 122, W. \& D. 67.

9 See, e.g., Il. III 63, Od. XX 366, Od. VI 121, Il. XIII 732, Hes., Theog. 37.

${ }^{10}$ See Od. XIII 229, XVIII 381; Il. XXIII 590; Hes., W. \& D. 67.

"See, e.g., Il. IV 309, XXII 382, XXIV 367; Od. II 124. 
that have the power to alter voos, sometimes for the worse ${ }^{12}$. The ways in which voos is open to outside influences show that it, like other psychic entities, did not have fixed boundaries. It could be changed.

A person appears in Homer, Hesiod, and the Homeric Hymns to identify closely with vós. He remains distinct from this psychic entity but it frequently acts as a seat of his true thinking and feeling ${ }^{13}$. Sometimes he may keep what his vós contains hidden from others, thus guarding his innermost thoughts ${ }^{14}$. Often in both Homer and Hesiod voos gives evidence of what the temperament or character of someone was like. It frequently seems to express his essential nature ${ }^{15}$. He usually acts in harmony with vóos. Sometimes he may control it (e. g., $O d$. XIX 42) or he may need to be aware of negative forces that can affect it (anger, e. g., gain, wine, or love) ${ }^{16}$. The condition of vós within seems of high importance, perhaps because a person identifies most closely with this psychic entity. All these passages show that the meaning of voos in these early authors was in no way a narrow, intellectual one, but rather a broad and wide-ranging one ${ }^{17}$. By its nature vóos appears very much to illustrate who a person is.

In the examination of vós in the lyric poets that will follow ${ }^{18}$, we will not discuss each passage in detail in the text but will list all occurrences in Appendix One. These occurrences will be divided into six Sections that will show the range of meaning of voos and the relationship a person had with this psychic entity ${ }^{19}$. These Sections will not be

${ }^{12}$ See, e.g., Il. IX 554, XIV 217; Od. XIX 479; H. Ven. 36; Hes., Theog. 537, fr. 239,3 .

${ }^{13}$ See, e.g., Il. XX 25, XXII 185, XXIV 377; Od. II 92, XIII 255, XIX 42.

14 See Il. I 363, XVI 19; Od. XXIV 474; Hes., $W$. \& $D$. 714; fr. 16.7.

is See, e.g., Il. XVI 688, XXII 382; Od. I 3, XXI 285; H. Her. 10; Hes., Theog. 262,1002 , fr. 43 a 76.

${ }_{16}$ See Il. IX 554, XIV 217; Hes., Theog. 122, W. \& D. 323, fr. 239,3.

17 For further discussion of this broad meaning of voos in Homer, Hesiod, and the Homeric Hymns, see Sullivan (note 1).

${ }_{18}$ On the meaning of vós in the lyric poets see the following: E. Lobel, AAKAIOY MEAH, Oxford 1927, p. XXXVI; R. Schottländer, "Nus als Terminus», Hermes 64, 1920, pp. 228-239; M. Treu, Von Homer zur Lyrik, Munich 1955, Zetemata 12, pp. 195-203; D. J. Furley, "The Early History of the Concept of the Soul", BICS 3, 1956, pp. 5-10; V. N. Jarcho, «Zum Menschenbild der nachhomerischen Dichtung", Philologus 112, 1968, pp. 166-172; S. M. Darcus, «Noos Precedes Phren in Greek Lyric Poetry", AC 46, 1977, pp. 41-51; Darcus (note 1), pp. 39-44; G. Luck, "Der Mensch in der frühgriechischen Elegie» in Gnomosyne, Festschrift Marg, Munich 1981, pp. 167-176; S. D. Sullivan, «Noos and Vision: Five Passages in the Greek Lyric Poets", forthcoming in SO 63, 1988, pp. 5-15.

19 Fragments of the different poets are numbered according to the following editions: Poetae Melici Graeci, ed. D. L. Page, Oxford 1962; Supplementum Lyricis Graecis, ed. D. L. Page, Oxford 1974 = (S.); Iambi et Elegi Graeci, ed. M. L. West, Oxford 1971, 2 vols. = (W.); Sappho et Alcaeus, Fragmenta, ed. E.-M. Voigt, 
determined by case, although a Section and case may correspond. The syntax of the different passages will not be discussed but it too can be found in Appendix One for each occurrence. Within the six Sections, poets will generally be treated in chronological order except for very similar usages of vós. For each instance we will suggest aspects of voos that may be prominent. (These will be indicated in Appendix One by «I» for intellectual, «E» for emotional, "V» for volitional, and «M» for moral.) In Appendix Two we will list all descriptive adjectives appearing with vóos ${ }^{20}$. To this analysis of vóos in the lyric poets we will now turn.

\section{The Passages}

Section A. vóos as Present, Active, or «Known» in a Person.

Of the 82 instances of voos in the lyric poets, 29 fall into this Section. In the occurrences where vós is present, active, or acted upon in the person, it appears in the nominative case. In the instances where it occurs as an entity "known", it is found in the accusative. In one passage, Solon says: «in every way the vóos of the immortals is hidden from men" (17 W.). Here vós appears to signify the thoughts, plans, and will of the gods ${ }^{21}$. Hesiod speaks of the voos of Zeus as one «hid-

Amsterdam 1971; Epigrammata Graeca, ed. D. L. Page, Oxford 1975 = (P.); Crossreferences are also given in App. One to Poetarum Elegiacorum Testimonia et Fragmenta, ed B. Gentili and C. Prato, Leipzig 1979, 1985, 2 vols. = (G.-P.).

${ }^{20}$ Works consulted for this article include the following: A. W. H. Adkins, Poetic Craft in the Early Greek Elegists, Chicago 1985; A. P. Burnett, Three Archaic Poets, Cambridge, Mass., 1983; D. A. Campbell, Greek Lyric Poetry, A Selection, London 1967; Greek Lyric, I, Cambridge, Mass., 1982; The Golden Lyre: The Themes of the Greek Lyric Poets, London 1983; J. Defradas. Les élégiaque grecs, Paris 1962; R. L. Fowler, The nature of Early Greek Lyric: Three Preliminary Studies, Toronto 1987; H. Fränkel, Dichtung und Philosophie des frühen Griechentums, Munich $1962_{2}$; A. Garzya, Teognide, Elegie, Libri I-II, Florence 1958; D. E. Gerber, Euterpe: An Anthology of Early Greek Lyric, Elegiac, and Iambic Poetry, Amsterdam 1970; B. van Groningen, Theognis, le premier livre, Amsterdam 1966; T. HudsonWilliams, Early Greek Elegy, London 1926; G. M. Kirkwood, Early Greek Monody, Ithaca, N. Y., 1974; D. L. Page, Sappho and Alcaeus, Oxford 1955; Further Greek Epigrams, Cambridge 1981; A. J. Podlecki, The Early Greek Poets and their Times, Vancouver 1984; H. D. Rankin, Archilochus of Paros, Park Ridge, N. J., 1977; R. Renehan, "The Early Greek Poets: Some Interpretations", HSCP 87, 1983, pp. 1-29; J. Tarditi, Archiloco, Rome 1968; M. Vetta, Teognide, Libro Secundo, Rome 1980; M. L. West, Studies in Greek Elegy and Iambus, Berlin 1974. See also other references in note 18 above. These works will be referred to by author's name or author's name and brief title.

${ }_{21}$ See Fränkel (note 20), p. 264. 
den» (fr. 16,7) and "difficult for mortals to discern» (W. \& D. 483). In Homer Zeus' "hiding" something in his voos is mentioned in a situation involving the gods (Od. XXIV 474); perhaps this voos is concealed from gods as well as human-beings. Solon refers to the voos of all the immortals as hidden. Clearly it would be valuable for human-beings to have awareness of its nature, since it is clearly thought to affect significantly the events of their lives ${ }^{22}$.

Semonides refers to the voos of human-beings in 1,1-8 W.:

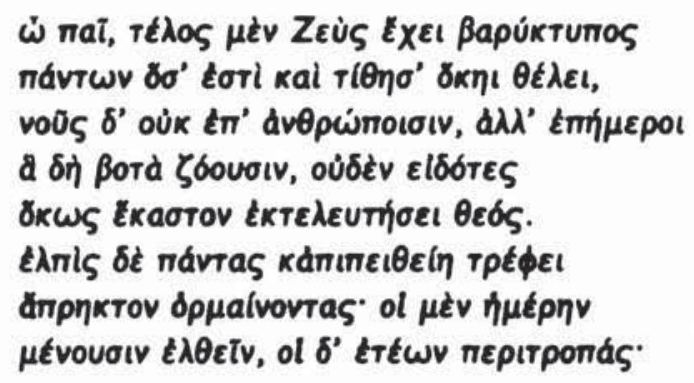

«Boy, loud-thundering Zeus holds the outcome of all things that are and places it as he wishes. Nós is not in men but, subject to the day, they live like grazing animals, knowing in no way how the god will bring each thing to completion. Hopes and confidence nourish us as we ponder the impossible. Some wait for the day to come, others, the turnings of the years" ${ }^{23}$. Two features of human-beings are prominent in these lines. First, they lack voos. In this context Semonides seems to contrast human-beings with the gods. The latter apparently have vós and it is of a kind that allows them to "hold the outcome» of all events. They evidently see this outcome and have the power to impose it ${ }^{24}$. Men have no awareness of the rélos that awaits their actions nor any control over that $T E \lambda \mathcal{L} \varsigma^{25}$. Instead of a clear apprehension of events, humans have «hope and confidence» which may lead them to consider

${ }^{22}$ At Arch. 94,6 W. mention is made of something occurring «by the voos of the Olympian gods" (App. One, 2). The context, however, is not clear.

${ }^{23}$ For a discussion of this passage see especially Fränkel (note 20), pp. 230-231, Renehan (note 20), pp. 3-11, A. Carson, «How Bad a Poem is Semonides Fragment 1?" in Greek Poetry and Philosophy, ed. D. E. Gerber, Chico, Calif., 1984, pp. 61-68, and D. E. Gerber, "Semonides, Fr. 1 West: A Commentary" in Greek Poetry and Philosophy, op. cit., pp. 125-128.

${ }^{24} \mathrm{Cf}$. Theog. 142 where uthe gods complete $(r \varepsilon \lambda \in \omega)$ all things according to their voos" (App. One, 61) and Theog. 202 where "the voos of the gods prevails" (App. One, 13).

${ }^{25}$ Cf. Theog. 135-136: «nor does any person act, knowing in фpéves whether it will turn out in the end ( $r E \lambda$ los) for good or for ill" and Theog. 1075-1076: "iit is

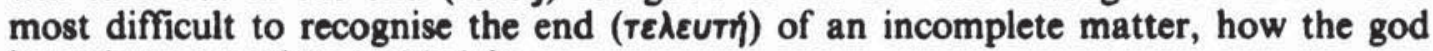
intends to complete ( $T \varepsilon \lambda \varepsilon \omega)$ it». 
actions that will not "reach an end" (ämpрктоv). Consequently, their attitude is one of waiting and hoping, either for the "day" or the "years", and the changes that these may bring.

The second feature of human-beings is that they are «subject to the day" ${ }^{26}$. They are somehow moulded by the "day" that they encounter. In Homer voos is specifically mentioned as the part of a person affected by the "day». At $O d$. XVIII 134-137 Odysseus says that in men voos «is such as is the day that the father of men and gods brings upon them ${ }^{27}$. Semonides compares humans with animals, moulded by the day, «knowing nothing" of how events will turn out. They are open to the events that come and are shaped by them.

By denying that voos is in human-beings, Semonides focuses upon a particular aspect of this psychic entity: its ability to «see» how events will turn out. In the gods vós easily performs this function. But, regarded in this light, voos becomes something outside the range of man. His essence as "mortal» may be defined by its very absence. In place of vós, Semonides defines man by the presence of something else, namely "hope and confidence». These, however, lead only to considerations that prove impossible or incapable of fulfillment (6-7). Because they lead to such considerations, these two qualities give evidence that voos in truth is absent.

In Sim. 8,10 W. (= Sem. 29 D.), voos is ascribed to mortals but is said to be of a negative nature ${ }^{28}$. In lines $1-9$, the poet says that the young man never imagines that old age or death will come. He has a

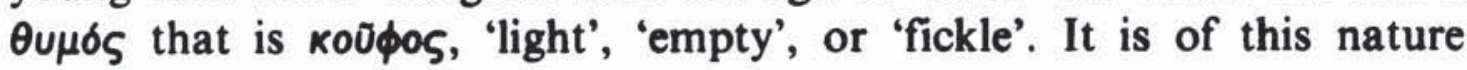

26 I follow the interpretation offered of $\ell \phi \gamma \mu \varepsilon \rho{ }^{\prime}$ given by H. Fränkel in «Man's "Ephemeros" Nature according to Pindar and Others", TAPA 77, 1946, pp. 131-145 $=$ Wege und Formen frührriechischen Denkens, Munich $1960_{2}$, pp. 23-29, and (note 20), pp. 148-151. This view is found also in E. Vermeule, Aspects of Death in Early Greek Art and Poetry, Berkeley 1979, p. 24. Different interpretations of the term are offered by M. Dickie, "On the Meaning of tфrjepos", ICS 1, 1975, pp. 7-14: "shortlived" and G. Fischetti, "Tre note greche», $A I V$ 132, 1973-1974, pp. 155-206: «like the day". Fränkel's interpretation, however, seems most appropriate for the poem of Semonides, especially in light of the reference to the "day" in lines 6-8. On these lines see also the remarks of Gerber (note 23), pp. 127-128, and Fowler (note 20), p. 114, n. 80 .

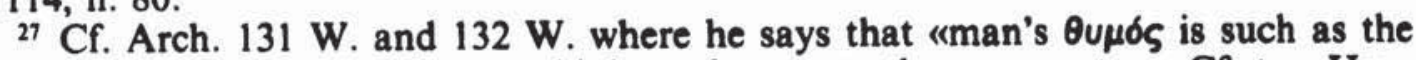
day brought by Zeus" and men "think as the events they encounter". Cf. too Hes., $W$. \& $D .793$ where a person's relationship to voos is strongly affected by the day on which he is born. See also below on Arch. 130,5 W., Sol. 27,11 and 13, and Stes. $P$. Lille 76abc 207 (App. One, 57, 21, 54, and 80) for the connection of voos with the "day".

${ }_{28}$ The authorship of the poem is in question and it may belong to either poet or perhaps to someone else. For a discussion of this question see Gerber (note 20), p. 64, West (note 20), p. 179, and Adkins (note 20), p. 167. 
because of the false hopes that "grow in his chest»" 29 . This «light» $\theta u \mu \delta 5$ suggests a lack of experience on the part of the young person. $\mathrm{He}$ also

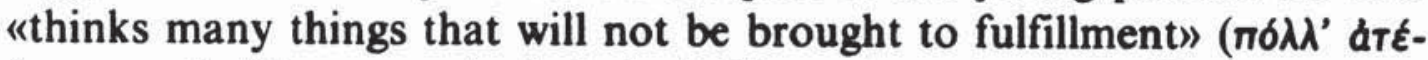

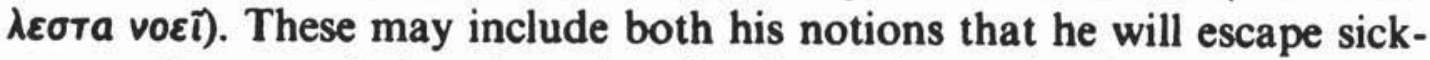
ness and age and the plans for the future he makes in light of such

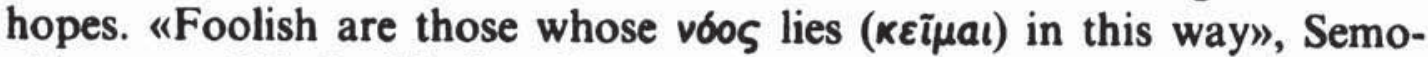
nides says (10). In this line the poet sums up the attitude of such young people. They are 'fools' (vinmot). Here voos seems associated with

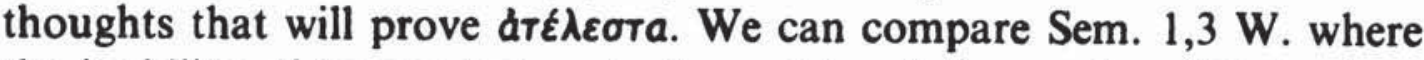
the inability of human-beings to be certain of the "end" of their plans was expressed in terms of their not having voos. Instead, they have «hope and confidence» which lead them to consider things «that will

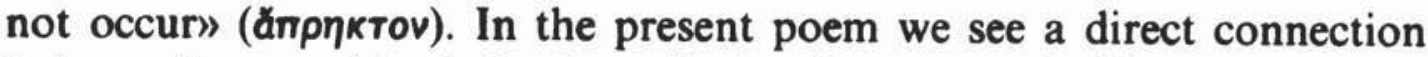

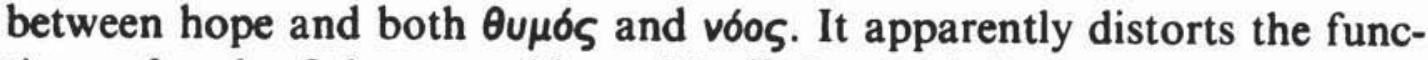
tions of each of these psychic entities ${ }^{30}$. It especially prevents the young person from realising that the "time of youth and life is short" (10-12). It does harm by keeping far away all thoughts about what must be the inevitable "end" of human life.

Homer had spoken of youth having a negative effect upon vós (Il. XXIII 590, 604). Theognis too will refer to "youth and young impetuosity" making vóos «fickle» $(629$, App. One, 69). Solon will mention vóos being "strengthened" in middle age $(23,11$ W., App. One, 21). But Mimnermus will say that "old age» harms vóos (5,8, App. One, 67). The passage of time clearly changes this psychic entity.

In another passage, Theognis mentions a human voos and its relation to Aupós (631). "The person in whom vóos is not stronger

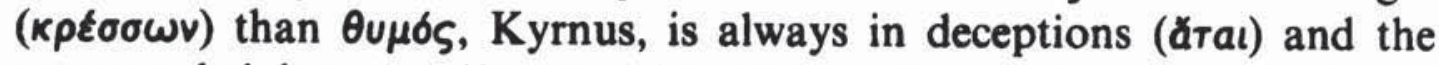

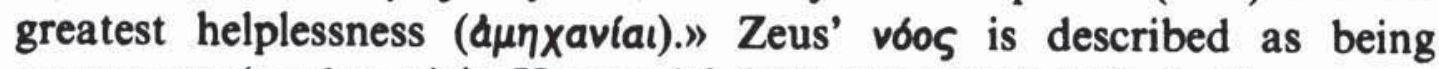

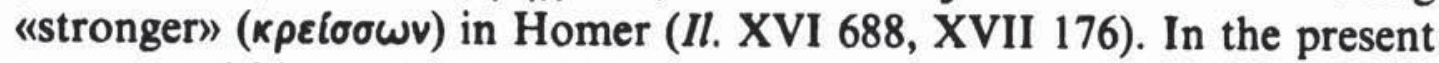
passage, within the human, Theognis says that vós should be more forceful than $\theta u \mu \delta \varsigma$. A voos "weaker than $\theta u \mu \delta \varsigma$ " results evidently in some

29 On the meaning of koöфos see Campbell, Golden Lyre (note 20), p. 213, and Adkins (note 20), p. 170. For the negative effect of hope cf. Solon 13,6 W.: "gaping we take delight in empty (кo0̈фos) hopes". Contrast, however, the positive effect of hope on Persephone's vós in H. Cer. 37. Below we will hear of a koüфos vós at Theog. 498 and 580 (App. One, 72 and 44). We will also hear at Theog. 629 (App.

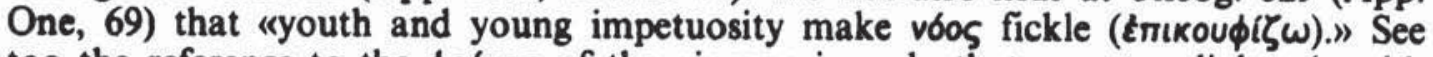
too the reference to the фpéves of the «inexperienced" that are "too light" (кouф6тepal) in Pind., Ol. VIII 61.

${ }^{30}$ For the connection of vós and $\theta u \mu \delta ́$, , see also Hom., Il. IV 309, Od. XIV 490, Theog. 375 (App. One, 24), 629-630 (App. One, 69), 631 (App. One, 5), and 1053 (App. One, 20). 
form of poor thinking and judgement. This makes the person a victim to «deceptions» and «helplessness». The importance of voos as a seat of thought and inner perception and its role in affecting behaviour is emphasized in these lines.

Elsewhere Theognis makes two general remarks about vóos. At 622 he says that everyone honours the wealthy man and treats the poor one with contempt. "The same (aúrós) vóos is present in all men». In this instance vós signifies the attitude or opinion found in all people. It sums up the way in which they perceive other human-beings ${ }^{31}$. At 1185 Theognis says that "voos is a good thing and the tongue. These grow in few men who are stewards of them both". In other passages too Theognis will relate voos and tongue, saying that both "grow in the chests of the wise" (1163, App. One, 15) and that the drunk person is not "master" of both (479-480, App. One, 60). At 760 he refers to them also in asking Apollo "to guide astraight his voos and tongue" (App. One, 78$)^{32}$. In the present passage Theognis appears to lament that the intelligent do not speak well and those who may be eloquent are not necessarily wise. Clearly vóos over which one is a "steward" is an asset desirable in people. If one is a "steward" of tongue as well, it is even better.

In other passages of Section A vós is qualified in various ways. At line 88 Theognis mentions a "trustworthy" voos: «if you love me and

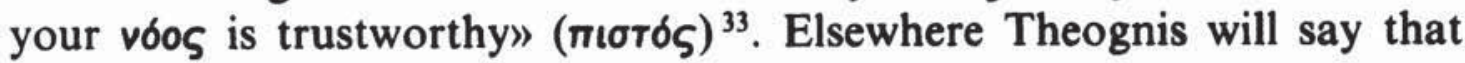

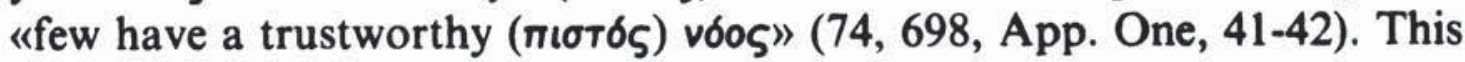
passage suggests that a "trustworthy" vóo entically. There will not be a discrepancy between inner person and outer behaviour. Homer speaks of this kind of discrepancy (see, e.g., Od. II 92 and XIII 255) as does Hesiod (W. \& D. 714). We see in this reference to vóos its importance as a seat of the person's true feelings, its ability to differ from outer behaviour, and its desirable condition described by the adjective 'faithful' or 'trustworthy'.

${ }^{31}$ Fowler (note 20), pp. 43-44, points out that this line of Theognis and several others mentioning vóos in Archilochus, Solon, and Theognis can be called upseudoformulae" since the same words appear in the same metrical position. These passages include the following: Arch. 185,5 W.; Sol. 11,6 W.; Theog. 74, $88=1082 \mathrm{~d}$, $498,580,622,792,814,898$, and 1016.

${ }_{32}$ Cf. too Hes., fr. 150,14 where "voos is above the tongue" and Sol. 27,13 W. where in the seventh group of seven years a man is "best in voos and tongue" (App. One, 54). See also the opposition of voos and tongue in Sol. 34,3 W., Theog. 91, and 365 (App. One, 51, 39, 32).

${ }^{33}$ This passage of Theognis will be discussed more fully below with lines 87-92 in Section C (App. One, 38-39, 46). 
In other passages vóos is of a negative nature. At 4,7-9 W., Solon says: "the voos of the leaders of the people is unjust, for whom, from their great insolence ( $\tilde{\beta} \beta$ p $1 \zeta$ ), the suffering of great pains is made ready, since they do not know how to check their great prosperity" (kopos). This passage shows certain important features of voos. First, it is associated with justice and its opposite, ößpı. The latter is related to the presence of kópos. Elsewhere too such an association of vós is mentioned. Hesiod speaks of Dike "telling the voos of unjust men" (W. \& $D$. 260). Solon will relate voos to both ößpıs and kópos (4 c 3; 6,4, App. One, 48,11$)$. Theognis too will associate voo 5 with justice or its absence. in several passages ${ }^{34}$. Second, voos seems to function as the seat of the thoughts, plans, and will of the leaders. It seems to be a seat too of their moral character and disposition ${ }^{35}$. Because they are insolent and incapable of handling "great prosperity", punishment awaits them. The source of their behaviour seems largely to be their voos which is «unjust» in nature.

In another poem Solon again describes vóos in a negative fashion. In 11,3-8 W. he criticises the Athenians for failing to perceive the intentions of those seeking power. He says of them: each of you walks with the steps of a fox but to all of you together the vós is empty (Xaũvos). You look at the tongue and words of a wheedler but do not see the deed that is being done.» Solon suggests that the Athenians are clever enough as individuals but in terms of judgement of leaders, they display an "empty" vóos. This pays attention only to what the leaders say and fails to grasp what they are doing. An «empty» voos does not function well in regard to inner or penetrating sight. It is «empty» of any capacity to go beyond appearances and to grasp reality, a capacity associated with voos. Instead, it «sees» only the surface ${ }^{36}$.

At 6,4 W. Solon mentions yet another negative form of vós. He says: «thus the people would best follow their leaders, neither left too

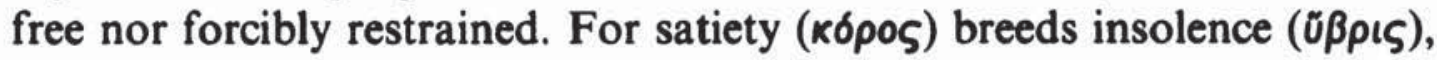
whenever abundant prosperity follows men whose vóos is not appropriate» (äprıৎ). The adjective àprios means 'complete', 'suitable', 'exactly

${ }^{34}$ See Theog. 154, 202, 373-380, 395, 792, and 897-900 (App. One, 12-14, 16, 23 , and 37).

${ }^{35}$ Cf. Sol. 22 a W. where Solon says: «he will not trust a leader who errs in his

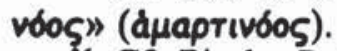

36 Cf. Pind., Pyth. II 59-61 where a xa0va nрănis fails to grasp a present situation and engages in fruitless struggles. This "empty" voos may be similar to the ko0фos voos referred to by Theognis at 580 and 498 (App. One, 44, 72). 
fitted', or 'appropriate' ${ }^{37}$. People who do not have a vós «fitted" for

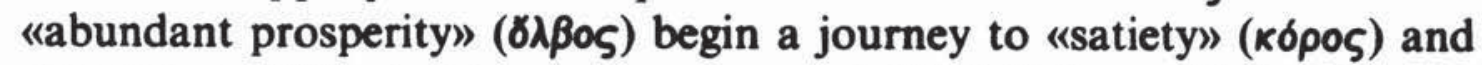
«insolence» ( $\tilde{\beta} \rho \mathrm{p} \iota \varsigma)$. Above, as we saw, at 4,7-9, Solon said that leaders with an "unjust» voos face punishment because of their üßpıs and kópos. In the present passage he clarifies the sequence by which they err ${ }^{38}$. Nóos in this passage signifies the capacity a person has for adjusting to "prosperity". When this comes, someone's thinking and attitudes are necessarily affected. If voos is not «appropriate», it apparently engages in wrong thinking and makes incorrect judgements. The consequences of these, "satiety" and «insolence», are totally negative in nature ${ }^{39}$.

In a few passages of Section A vóos is described as an active agent.

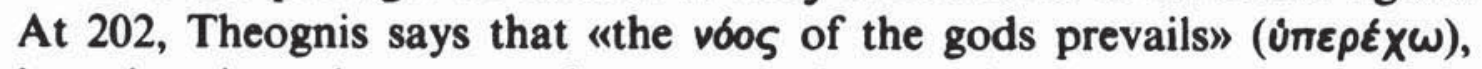
in a situation where a greedy man acquires wealth unjustly. "In the end evil befalls" such a person (202). Theognis contrasts wealth acquired in this fashion with that coming to a man "from Zeus and with justice» (196). This just form proves lasting. Homer and Hesiod describe Zeus' vóos as "stronger», «inescapable», and "impossible to avoid or to frustrate» ${ }^{40}$. Here in Theognis the voos of the gods in described as "prevailing». It is also one associated with justice. It is the gods' "will» and «intention» that just wealth endure and unjust, fail. This voos always comes to pass.

Theognis refers to the voos of Zeus in lines 373-380. At 375 he says

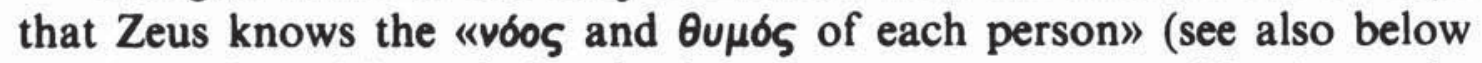
on App. One, 24) and that he has the greatest power. He then asks Zeus, possessing such knowledge and authority: «how does your vós endure to hold wicked persons and the just man in equal regard,

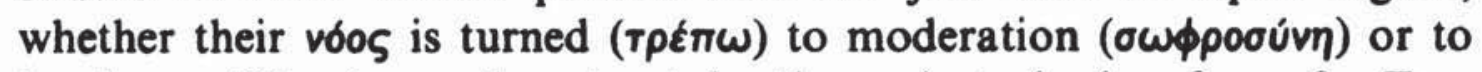

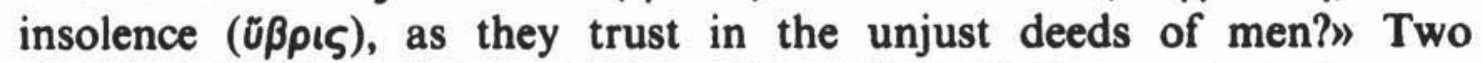
pictures of voos are given in these lines. That of Zeus controls humanbeings. To some it may seem that the evil and good are treated alike by this voos but, as we heard at line 202, "the voos of the gods prevails" and it is one concerned with justice. The voos of humans described in

${ }^{37} \mathrm{Cf}$. Solon's other uses of this adjective at 4,32, $39 \mathrm{~W}$. and $4 \mathrm{c} 4 \mathrm{~W}$. Cf. too Theognis who says at 946 that he must "think all things appropriate» (đpria návia voeiv).

${ }_{38}$ Theognis echoes these lines at 153-154 (App. One, 12), changing the general reference of "men" to "an evil man». For the association of oßpı 5 and kopos see also Pind., Ol. I 55-57, XIII 10, and Her. VIII 77,1. See too the note of Campbell, Lyric Poetry (note 20), p. 245, and Gerber, Euterpe (note 20), p. 135.

${ }^{39}$ Cf. too the association of vós with kopos at Sol. 4 c 3-4 W. (App. One, 48).

${ }^{40}$ See Il. XVI 688, XVI 176; Od. V 103, 137; Hes., Theog. 613; W. \& D. 105. 
these lines is clearly the seat of their moral character. Zeus knows this vóos. It can turn to "moderation» or to «insolence». In the latter case, it is associated with "unjust deeds». Once again, as in Sol. 4,7 W. and 6,4 W. (App. One, 9, 11), we see vós related to justice. It acts as the seat of someone's inclination to admirable or immoral behaviour. Intellectual, emotional, volitional, and moral aspects appear in this reference to vóos.

Six passages describe the activity of vós in human-beings. At 11631164 Theognis says: «eyes, tongue, ears, and voos grow ( $\phi \dot{u} \omega)$ in the middle of the chest of men who are wise" (ouvetol). Here, as in Homer and Hesiod, and also in other passages of Theognis, voos is located in the chest region $(\sigma r \dot{\theta} \theta \varepsilon a)^{41}$. In the "wise» eyes, tongue, ears, and vós work, it seems, at a deep level ${ }^{42}$. Their apprehension of events takes place on an inner level. In these people vóos perhaps functions well with regard to "inner vision" or understanding of the meaning of events. This couplet of Theognis may. suggest too that the wise keep hidden what they see, say, hear, and think. One feature of voos found in Homer and Hesiod is its "hidden" nature ${ }^{43}$. Persons can conceal their true thoughts and feelings in this psychic entity. Theognis may be suggesting that the wise have a "concealed" voos. Such a voos may prove to be a problem for others but can be a valuable asset for the person himself ${ }^{44}$. Someone wise probably conceals what he is actually thinking, desiring, or feeling. In this way he can guard himself from others.

At 395-397 Theognis associates voos with justice ${ }^{45}$. He says that poverty clarifies which man is 'worthless' ( $\delta \varepsilon i \lambda \delta \varsigma)$ and which, a «much

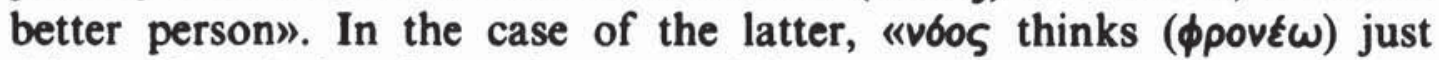

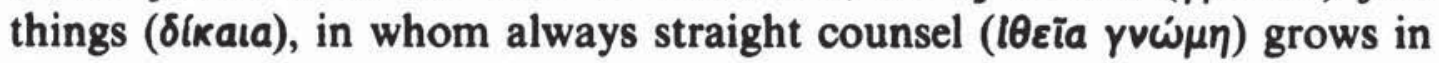
the chest». In the case of the former, "voos follows neither in good or evil situations». In poverty vós in a good man thinks just thoughts ${ }^{46}$. This voos is closely connected with his character and disposition. This person poverty cannot harm. "Straight counsel» is always present in him. This "counsel» may be associated with his voos. But in the

4 See, e.g., Il. III 63, Od. XX 366; Hes., Theog. 122; Theog. 121, 507, and 898 (App. One, 17, 74, 33). See too Scol. 889, 2 (App. One, 82).

${ }_{42}$ See other associations of vós and tongue above on Theog. 1185 (App. One, 7) with note 32.

${ }^{43}$ See above note 14 .

4 For a discussion of the meaning of this couplet see van Groningen (note 20), p. 423.

${ }_{45}$ See other such associations above on Sole 4,7 W., 6,4 W., and Theog. 377 (App. One, 9, 11, 14).

${ }_{46}$ Contrast the "unjust" voos described by Solon in 4,7 W. (App. One, 9). 
"worthless" man vóos is never present. He cannot cope with poverty and reveals by his thinking and behaviour his inferior nature. "Straight counsel» is missing in such a person. These two mentions of vós show how strongly Theognis associated it with moral behaviour. In the "worthless" man it is absent; its "presence» in the good person ensures just actions.

In lines 119-128 Theognis emphasizes the importance of the voos we encounter in others. He says that a wise man can usually spot phony

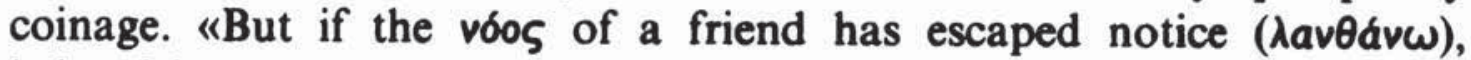

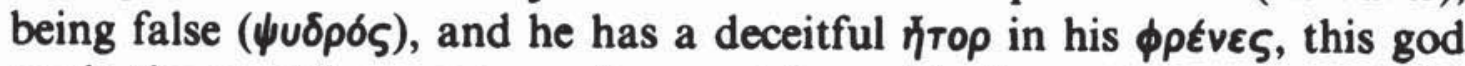
made the most base coinage for mortals and to know it is most painful

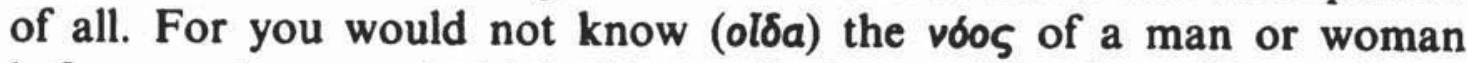
before you have made trial of it as of a beast of burden." He concludes these comments by saying that appearances can deceive. Here, as in Homer, Hesiod, and Theognis 1163, the «hidden" or "concealed" nature of voos is mentioned. If it is "false" and coupled with a «deceitful" "rop, the evidence someone gives of friendship may be entirely deceptive. Obviously this person's behaviour belies his true feelings and thoughts. He acts in one way, his voos in another. Other passages too of the lyric poets will emphasize this «hidden" nature of voos and the ability a person has to conceal his actual feelings in it ${ }^{47}$. In this psychic entity a person's true essence seems to be found. Ideally voos and behaviour will match. When they do not, the discovery of this situation can prove very painful to others.

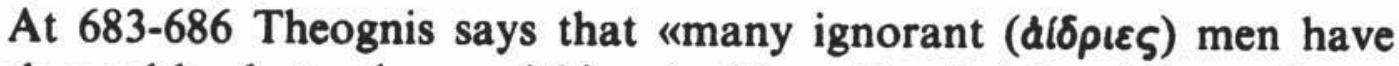
much wealth" but others, wishing 'noble actions' (Td ka)d $)$, are hampered by poverty. He says that 'helplessness' ( $\alpha \mu \eta$ Xavi $\eta$ ) attends both these groups: «money restrains the one, voos, the other». In the «ignorant" rich, vós is of a defective kind. It keeps these people in "helplessness». Although they have money, they do not seem to be capable of «noble behaviour». Homer (Od. XI 272) and Hesiod (W. \& D. 687) both refer to dïpein of vós, describing a lack of intelligence. Theognis seems to imply more a moral context in his use of the term in this passage $^{48}$. The possession of voos appears to be the source of good will and admirable, moral behaviour. Unfortunately, in his view, the wrong people have it.

47 See on Sol. 34,3 W. (App. One, 51), Theog. 74, 87-92, 365-368, 500, 598, 698, 814, 898, and 1016 (App. One, 23, 26-28, 34-35, 38-39, 41-42, 73) and Scol. 889,2 (App. One, 82). Cf. also Homer and Hesiod in note 14 above. See too the reference to the voos of the gods as dфavris in Sol. $17 \mathrm{~W}$. (App. One, 1).

48 See the comments of van Groningen (note 20), p. 269. 
In lines 1049-1054 Theognis refers to voos three times as he advises Kyrnus:

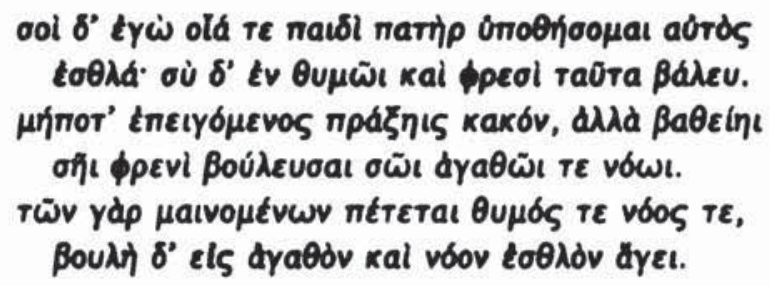

«I myself, as a father, his child, will give you noble advice. You place

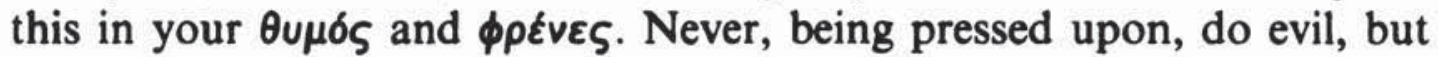
with your deep $\phi \rho \eta \dot{v}$ and good vós take counsel. For the $\theta u \mu \delta \varsigma$ and voos of those who are maddened flutter about, but counsel leads even the noble voos to good". This passage mentions three psychic entities,

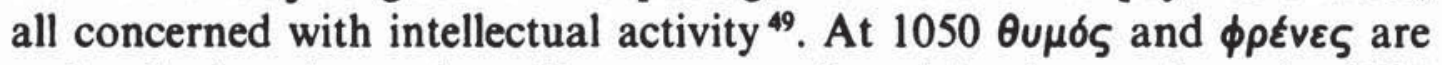
to be the locations where Kyrnus puts the advice he receives. At 1052 he is to "take counsel with his deep фpriv and good vóg". At 1053-

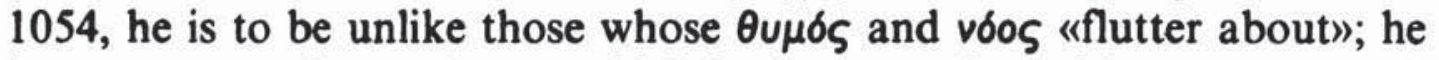

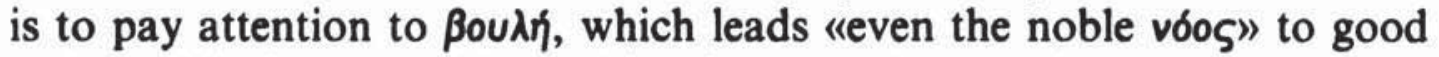
action. All three psychic entities function better when they are used calmly by a person. If Kyrnus acts in this manner, he will be led to good rather than evil actions.

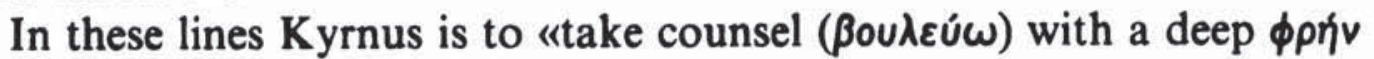

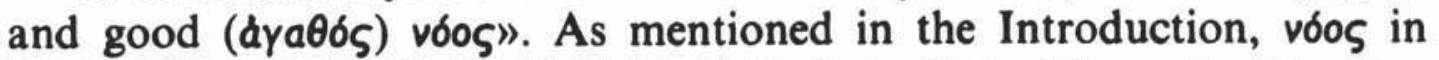

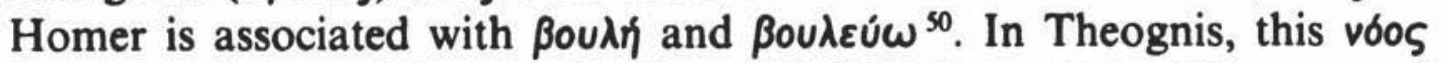
is a "good" one. Here, as in lines 683-686 (App. One, 19), a moral connotation may be present in voos. By its thoughts and desires, a "good" vóos may bring about admirable moral behaviour ${ }^{51}$. In line 1052 voos is an instrument or accompaniment with which Kyrnus can act (see below, App. One, 30). At 1053 Theognis says that the Oupos

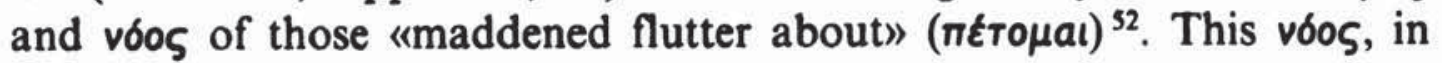
a negative condition, may cause reprehensible actions. Both psychic entities, "fluttering about", may not prove receptive to "counsel». As Theognis says in 1054 (see also below, App. One, 65), this «counsel»

49 For a detailed discussion of this passage see van Groningen (note 20), pp. 390391, and Darcus, $A C$ 46, 1977, pp. 47-51.

so See above note 4.

s1 Cf. too Theognis 395-397 (App. One, 16-17) discussed above where vós «thinks just thoughts».

${ }_{52}$ For the connection of voos and $\theta u \mu \delta \varsigma s$ see above on Theog. 631 (App. One, 5) and note 30 . 
can lead «even a noble vós to good action». This time vóos is called $\xi \sigma \theta \lambda \delta \zeta$, a description given of it also in Homer ${ }^{53}$. This adjective too suggests some moral involvement of voos. "Counsel" has the effect of leading such a vós to admirable behaviour. This line shows how strong an influence upon a person's actions vós can have. If it is «led to good", he acts admirably. Person and vóos thus seem to be closely identified.

In two passages of Section A v6os is acted upon. At Sol. 27,11 W. vóos in the sixth group of seven years is described as «being strengthened (катартú $\omega$ ) in all respects». Solon also says of the person of this age: "he no longer wishes as before to do the impossible». Above, in Sim. 8,1-10 W. (= Sem. 29 D.), we heard criticism of the young person for being filled with false hopes. He was described as «thinking many things that would not be brought to fulfillment» (7). We heard too in Sem. 1,1-8 W. how "hope and confidence" cause people to "ponder the impossible». Solon says that the person in his middle years no longer entertains impossible desires. The «strengthening" of voos, then, may involve some grasp or awareness of reality, namely of what the humanbeing can accomplish and what end awaits him.

This passage shows as well how time changes vóos. As described above in the discussion of Sim. 8, 1-10 W., voos is thought by the lyric poets both to be vulnerable to youth and also to be harmed by old age. In this passage Solon suggest that it is made stronger after the age of fourty. In the same poem, at 27,13 , he will say that in the seventh and eighth group of sevens, a person is "best in vós and tongue» (see below, App. One, 54). The "strengthening" of vós leads to a time of mental flourishing that lasts for fourteen years.

At Theognis 379 (discussed above with line 377, App. One, 14), vóos is described as "being turned to moderation or to insolence». This passage suggest the different moral attitudes that voos could express. The person's behaviour is determined by the "direction" of vós. Its influence in this regard seem very strong. Homer too had spoken of vóos as being "turned» (Il. XVII 546, Od. III 147, VII 263). It is clearly a changeable entity within the person.

In the remaining passages of Section $A$, voos is described as an entity "known» or "recognised». These passages suggest the important role that voos was thought to have within the person. At $897-900^{54}$,

${ }^{53}$ See $I l$. XIII 732, Od. VII 73; Hes., fr. 10 (a) 88 (possibly). See also references to a "noble" vós in Theog. 223, 792, and 1271 (see App. Two).

s4 For a discussion of these lines and their meaning see West (note 20), pp. 160161 . 
Theognis says that if the god, «knowing ( each person has", were to be angry with mortals for all they did, great suffering would befall "both the just and unjust man». As we have seen in other passages ${ }^{55}$, voos is related to justice. In this case it seems to be the source of just or unjust actions as well as of all the activities that human-beings engage in. In particular it is the well-spring of moral activity which, in all cases, seems to fall short of the perfect. Although this voos may on occasion be hidden from other human-beings, the gods "recognise» what kind each person has ${ }^{56}$.

In some circumstances a human-being may know the vóos of another. At 598 Theognis tells Kyrnus: «associate with other men who know (oloa) your vóos better». Nóos seems to be closely connected with the disposition or character of Kyrnus ${ }^{57}$. Theognis suggests that he will be happier with those who understand and sympathise with his way of thinking, his feelings, and his desires, all apparently to be found in vós ${ }^{58}$.

In two passages $367=1184 \mathrm{a}$, Theognis complains: «I am not able to know ( I please them neither by good deeds or bad". What the citizens are actually thinking and feeling cannot be detected by Theognis. Their voos is hidden from him. As we learned above on Theognis 121-128 (App. One, 18) vós can be concealed from others ${ }^{59}$. When this occurs, it can cause perplexity, as it does in Theognis.

At 439-440 Theognis observes: «foolish is the man who holds my vóos under surveillance but pays no attention to his own concerns» ${ }^{60}$. Here voos seems to be the source of Theognis' actions. Someone who is more concerned about what another is thinking, feeling, or willing to the neglect of his own affairs is "foolish». As in Sim. 8,10 W., a wrong

ss See above on Sol. 4,7 W., 6,4 W., and Theog. 154, 202, 377, and 395 (App. One, 9, 11-14, 16). See too below on Theog. 792, and Sim. 26A P. (App. One, 37 and 56).

s6 Cf. Hom., Il. XXII 382, Od. I 3, XXI 205, and Hes., fr. 43 a 76, where a form

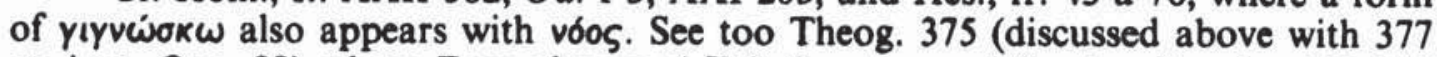

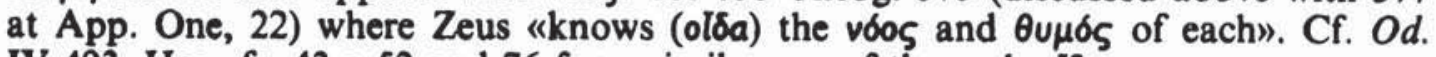
IV 493 , Hes., fr. 43 a 52 and 76 for a similar use of the verb olda.

37 See the perceptive remarks of van Groningen (note 20), pp. 237-238 on this passage.

58 Cf. too Theog. 125 (discussed above with 121 at App. One, 18) where he says:

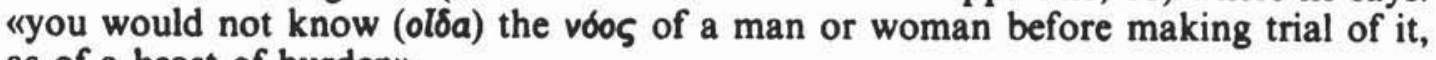
as of a beast of burden".

"See also note 47 for other instances of a «hidden" voos.

${ }^{60}$ For a discussion of this passage see van Groningen (note 20), pp. 175-177, and Renehan (note 20), pp. 23-24. I follow the text of the latter. 
way of thinking marks a person as vinıs, «lacking sense». In the case of both persons mentioned in the lines of Theognis, vós functions prominently as the source of their behaviour.

Section A: Observations. In these 29 passages vóos displays certain prominent features.

(1) First, it acts as an active agent within the person (App. One, 13-20). It can, e. g., "grow», «think just thoughts", «prevail», or «flutter about». Second, it can be "turned" in some direction or "strengthened" (App. One, 21-22). Person and vóos remain distinct but vóos strongly influences his behaviour.

(2) The passages in which vóos appears as a entity «known» (App. One, 23-29) illustrate its marked influence upon the actions of individuals. Such ocurrences suggest that a person's nature is to a large degree reflected in his voos.

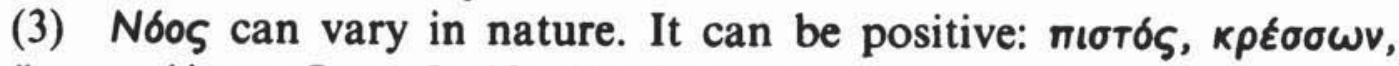

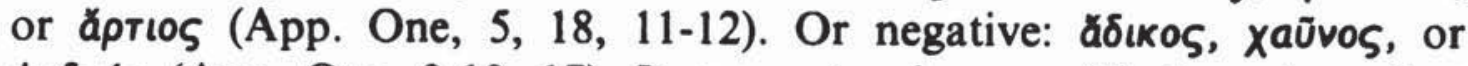

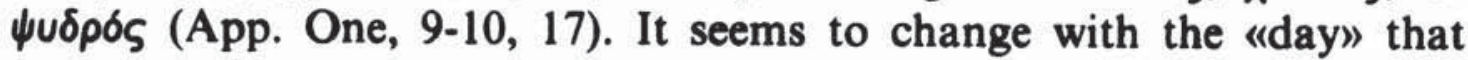
men encounter (App. One, 3) and with the years that pass by (App. One, 21).

(4) Noos is associated with moral behaviour, especially justice and its opposites, satiety and insolence (App. One, 9, 11, 13-14, 16-17, 2224).

(5) Within the person vóos can be «hidden» (App. One, 15, 18, 2628). It is also associated with the "tongue» (App. One, 7). It seems very much to function as a seat of a person's character, disposition, or temperament (see especially, 8, 18, 20, 22, 27-29). His essential nature seems to be found in vós.

Section B. A Person Acts in, by, or with voos.

Section B contains only three passages. In these voos serves as a location where a person acts, an instrument that he acts with, or as an accompaniment to his actions. The fragmentary nature of the evidence may partly account for the limited number of such occurrences of voos, but it may also be the case that it did not function frequently in this way. At Theognis 1052 (discussed above with lines 1049-1054, App.

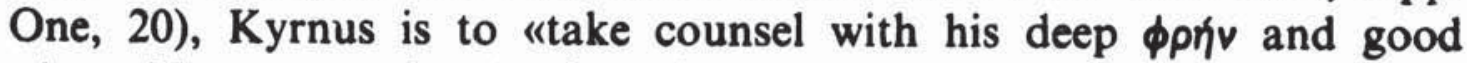
vóos". Here a "good" vóos is an instrument that Kyrnus uses, probably to form plans that have a moral aspect. At 1237 Theognis ascribes a similar function to vós when he tells Kyrnus: «strive to understand 


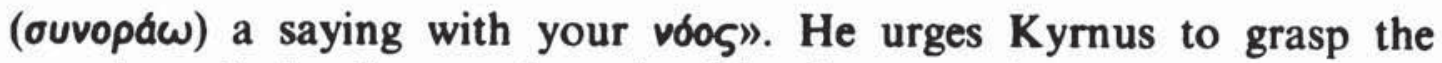
meaning of what he says by using his voos as an instrument. Noos too may engage in activity of its own in this situation and act as an accompaniment to Kyrnus ${ }^{61}$.

In the third passage of Section B Theognis tells Kyrnus: «check yourself in your vóos; let gentleness of tongue always follow. In truth the heart ( $\kappa a \rho \delta i \eta)$ of the worthless in rather sharp» ( $\delta \xi u \tau \varepsilon \rho \eta)$. Kyrnus is to curb what he may be thinking and always speak in a gentle way ${ }^{62}$. Several features of vós are apparent here. First, as we saw in Theog. 1185 (App. One, 7), it is connected with the tongue (see too note 32). Second, in this situation, it can differ from speech and thus, in its essence, be a "hidden" psychic entity ${ }^{63}$. In it are to be found Kyrnus' true feelings and reactions. Third, it seems to be an entity over which Kyrnus can exert some control ${ }^{64}$. He is to "check» the way he is thinking or feeling and to speak in a different way.

Section C. A Person Has a Direct Relationship with vóos.

In 21 passages of the lyric poets someone relates directly to voos. These occurrences suggest that a person exerted some control over this psychic entity. In ten passages the verb $\varepsilon_{\chi} \chi \omega$ appears. Someone either "has" vóos or "holds" it in some way. Both Homer and Hesiod also spoke of vós in this fashion ${ }^{65}$. At $96,2^{66}$, Sappho describes a girl absent in Lydia as «often holding her vóos here». Nóos seems able to visualize a far-off place. This function of vóos is found also in Il. XV 80-83 where it "leaps in thought" as a man remembers places he has visited.

Theognis mentions the vós that others have. He speaks of «testing"

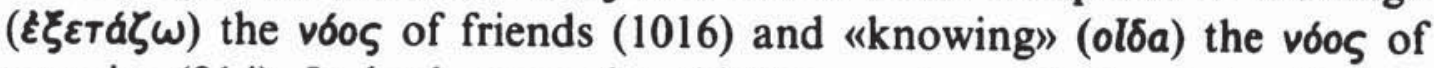
enemies (814). In both cases the "hidden" nature of vós is implied: it is something that Theognis has to search out. Archilochus describes a vixen that has a «cunning" (nukvós) vóos. At Il. XV 461 Zeus' vós is

\footnotetext{
${ }^{61}$ On this passage see Vetta (note 20), p. 46. 145.

${ }^{62}$ On this passage see Garzya (note 20), p. 199, and van Groningen (note 20), p.

${ }^{63}$ For other passages where this is so, see above on Theog. 121-128 (App. One, 18) with note 47.

64 Cf. Od. XIX 42 where Telemachus is told to "check» (kard ... loxd́vw) his voos. Cf. too Sol. 4 c 3 W. (App. One, 48) where one is to "place a great voos in measure".

65 See Il. IV 309, XXII 382; Od. II 124, XIV 490; Hes., Theog. 262.

${ }^{66}$ I follow the text of Page, Sappho and Alcaeus (note 20), p. 89, and Campbell, Greek Lyric (note 20), p. 120, who restore [v]ẅv.
} 
described as «wise», nukıvos. The wily nature of a fox, it seems, is to be found in its vós ${ }^{67}$.

At 792 Theognis expresses the wish that he «have a noble ( $\varepsilon \sigma \theta \lambda \delta \zeta)$ vós among good people, harming neither stranger nor citizen with baneful deeds, but being just». Once again we see vós associated with moral qualities, specifically with justice ${ }^{68}$. Here vóos is called «noble». As in other passages where this adjective appears ${ }^{69}$, it seems to have a moral connotation. This passage shows how closely a person identified with voos. In this instance it signifies the seat of Theognis' character and is related to his being a «just» person.

In another passage Theognis speaks of both vóos and $\phi \rho \varepsilon v \varepsilon \varsigma$ being «held» (87-92):

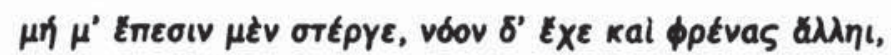
et $\mu \varepsilon$ фileis kal ool miotds tverti vóos.

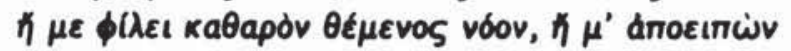

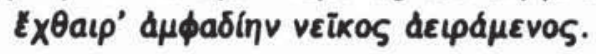

«Do not love me and hold your vóos and фрદ́ves in another direction, if you love me and your voos within is trustworthy. Either love me, putting on a pure (käapós) vós, or refuse and hate me, raising a quarrel openly. The man who with one tongue holds vós in two ways is a terrible companion, Kyrnus, better an enemy than a friend." These lines contain four mentions of vós. They emphasize in particular its hidden nature and the ways in which exterior behaviour can fail to reflect what it is really like. In a way similar to Hesiod in $W$. \& $D$. 714, Theognis pleads for behaviour to be an authentic expression of vós. Kyrnus is to hate or to love, according to his actual feelings.

In these lines Theognis first tells Kyrnus not to hold both his фpevves and voos "in another direction», if his affection for Theognis is real and

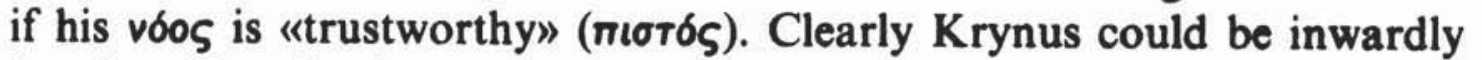
keeping his affections elsewhere. He should not, if his outer show of affection is to be trusted as a expression of his actual thinking. Next, Theognis calls for Kyrnus to put on a "pure" voos in showing love.

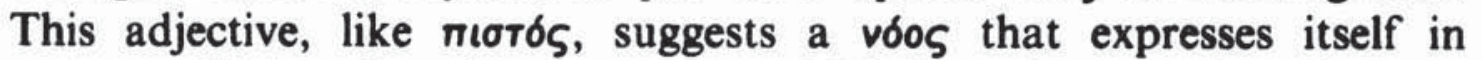
actions which reflect its true nature. Thirdly, Theognis describes the person with «one tongue» and «divided» voos as belonging most fit-

${ }^{67}$ For the context of this poem of Archilochus see Campbell, Golden Lyre (note 20 ), p. 130, and Burnett (note 20), p. 63.

${ }_{68}^{68}$ For other instances see on Theog. 898 (App. One, 23) above with note 55.

${ }^{69}$ See above on Theog. 1054 with note 53. See too App. Two. 
tingly to the realm of "enemy" ${ }^{70}$. In his speech Kyrnus evidently expresses friendship but his vós contains both friendly and unfriendly thoughts. Since his words reflect only one of the directions his voos moves in, they are deceitful. $\mathrm{He}$ is, as Theognis describes someone in

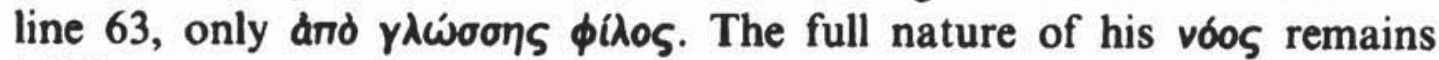
hidden.

This passage of Theognis illustrates how closely vós is connected with the attitude and feelings of an individual. It is clearly involved in emotion in this situation. The love or hate that Cyrnus experiences is centered in vóos. His behaviour, ideally, will perfectly reflect what his vóos thinks, feels, and desires. If it does not, vóos still remains the seat of feeling, only in this case its true nature is hidden and protected by deceptive actions ${ }^{71}$.

In another passage Theognis tells Kyrnus: «do not hold your vóos on impossible deeds" ( (ппрүкта). We heard above that humans, buoyed up by hope, consider things that will be impracticable (Sem. 1,3 W., App. One, 3). This is especially true of the young person (Sim. 8,10 W., App. One, 4). In middle age a person ceases to set his heart on «impossible deeds» (Sol. 27,11 W., App. One, 21). Theognis suggests that this type of thinking is within one's control and urges against it. Noos is better employed in dealing with deeds that can be brought to fulfillment.

In five other passages Theognis describes different kinds of vós that people can have. In these instances the degree to which a person's disposition or character is to be found in vóos is very marked. At 74 he warns Kyrnus not to share all his activities with his friends, since "few

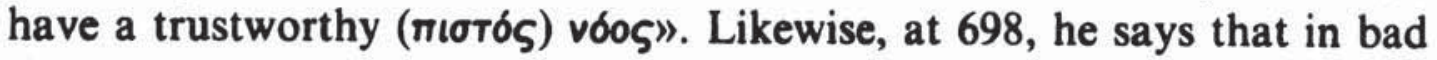
times he is not surrounded by friends since «few have a trustworthy (miotós) vóos". Once again we see the "hidden" nature of voos: people seem to be friends in their outward actions but fail to be so in fact. At Theognis 87-92 (discussed above, App. One, 38), we heard that a utrustworthy" voos shows forth its true thoughts and feelings. This is a rare occurrence in men, in Theognis' view.

At 109 Theognis says that the 'worthless' $\left(\delta \varepsilon \varepsilon_{1}()_{0}\right)$ are never grateful

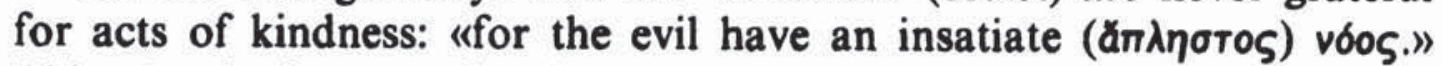
This voos is the seat of selfish desires. It is never satisfied. It resembles the voos that is not 'appropriate' (aptios) described by Solon (6,4 W.)

${ }^{70}$ See the connection of voos and tongue above on Theog. 1185 (App. One, 7) with note 32 .

7 For further discussion on this passage, see above on line 1053 (App. One, 20), Darcus, AC 46, 1977, pp. 41-45, and Campbell, Golden Lyre (note 20), p. 25. 
and Theognis (154), one that did not know how to cope with prosperity and led to hybris. Theognis speaks of a negative vóos too at 580. A woman says: «I hate the evil man... having the empty (кoũфos) voos of a small bird. ${ }^{72}$ Like the koũфos $\theta u \mu \delta 5$ mentioned above in Sim. 8,1-10 W. (App. One, 4), this type of vós appears to be «empty», «fickle», or "unsubstantial» ${ }^{73}$. As we will hear below, wine can make vós "fickle» (Theog. 498, App. One, 72). In the present passage the intellectual power of an evil person appears to be limited and his thoughts, trivial.

At 1267 Theognis says that a horse and child "have a similar

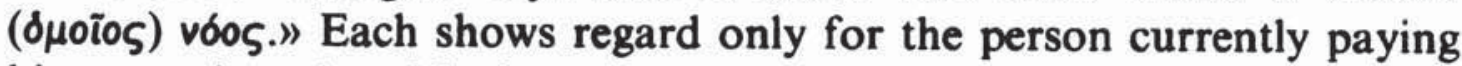
him attention. As with the other negative descriptions of voos, undesirable and unpleasant traits of character are associated with it. The person seems very much to be identified with this psychic entity.

In three passages a person exerts some control over voos with the verb riø $\eta \mu$. At Theognis 89 (discussed above with 87, App. One, 38), Kyrnus is to "put on a pure vóos." This was one honest in the affection it showed. Scol. 901,2 also mentions this kind of voos, speaking of a woman, involved in a holy offering, who "puts on a pure voos." In this context the adjective implies: «free from guilt». Solon at $4 \mathrm{c} 3 \mathrm{~W}$. gives advice: «you, keeping quiet your mighty jrop in your фpéves, who drove into satiety (kópos) of many good things, put your great ( $\mu \varepsilon \gamma a \varsigma)$ vóos within measure. For neither will we be persuaded nor will these things be appropriate (ðртıa) for you.» Here vós is associated with кópos, as it is in Sol. 6,4 W. (App. One, 11), where it «breeds hybris for those whose vós is not appropriate» (aprios). In the present passage of Solon кópos appears to have «enlarged" vóos. A "great» vós in this context is negative. Elsewhere the adjective is used positively of this psychic entity ${ }^{74}$. The call to place such a voos «in measure» shows that a person had some control over it, just as in Theog. 365 (App. One, 32), where Kyrnus is to "check himself» in his vós. Solon urges moderation in desires. All things otherwise in the future will not be «appropriate" for these people because they will not take place in a way that suits what their "great» vóos would wish.

The remaining instances of Section $\mathrm{C}$ suggest differing relationships between person and voos. At 581,1, Simonides asks: «who, trusting in

72 I follow West in ascribing the vóos to the man. See too his suggestions of the identity of the female speaker in (note 20), p. 156. In contrast, Garzya (note 20), p. 92, and van Groningen (note 20), p. 229 ascribe the voos to the woman herself.

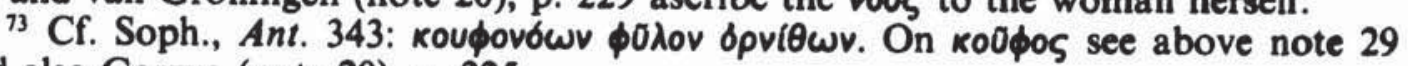
and also Garzya (note 20), p. 225.

${ }^{74}$ See H. Cer. 37 and Hes., Theog. 37. 
his voos, would praise Cleobulus?» In his view, the ruler of Lindos was foolish in his claim that his stele would withstand the effects of time. He failed to realise that "all things are less than the gods", especially the works of men (581,5-7). This passage suggest that the function of voos was considered valuable, its judgements sound. It is associated here with the awareness that the wise have about what endures and what does not. It has some form of uinner vision" in this regard.

In one fragment of Alcaeus, 363,1 someone usends his vós soaring high" ( $(\varepsilon \hat{\varepsilon} \rho \omega)^{75}$. A person does this perhaps in pride. If this is the situation, this vós resembles the "great" vóos mentioned by Solon that is swollen by ambition. A person evidently has some control over vós but whether he can safely «lift it on high" is doubtful.

At 34,1-6 W. Solon speaks of vós in a way that illustrates its «hidden" nature. He says that certain men thought that he would act on their behalf and make them rich. They imagined that his kind words to their enemies simply concealed harsh intentions for the future. Soion says that they hoped that he, "uttering smooth complaissance would show forth a harsh (тpaxús) woos." But, in thinking this way, "they pondered empty considerations" (4). Here an assumption is made that outer behaviour does not reflect vós. Solon's true thoughts and plans are supposed to be concealed within. In fact, in this situation, voos and outer behaviour did match, much to the chagrin of Solon's enemies.

Finally, in Section C, Theognis speaks twice of the "destruction" of voos, brought about by the person himself. At 35-38 he suggests that noble behaviour depends on what voos has been exposed to. "You will learn noble acts ( $\dot{\varepsilon} \sigma \theta \lambda \dot{\alpha})$ from noble men ( $(\varepsilon \sigma \theta \lambda o t)$. If you mingle with evil persons, you will destroy ( $\left.\alpha_{n} \delta \lambda \lambda u \mu l\right)$ even the voos you have.» The association with morality that voos has is evident here. It appears in Kyrnus to be the set of his intellect, will, and good character. If he keeps bad company, he is in danger of "losing" or "destroying" this voos. Right associations and good counsel are needed to sustain this vós with its potential goodness. At 1271 he says that someone «has

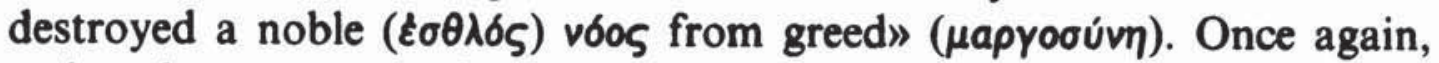
as in other passages of Theognis, vóos is called "noble»" ${ }^{76}$. Here, it was one with positive moral inclinations. Excessive desires of some sort, however, have removed its nobility. In both these passages the control that a person exerts over vós is very apparent. Moral behaviour is to

75 I follow here the text and interpretation of Campbell, Greek Lyric (note 20), p. 394.

${ }^{76}$ On this adjective see above on Theog. 1049-1054 (App. One, 20) with note 53. See too App. Two for other instances in Theognis. 
a large degree dependent on the type of voos that one strives to maintain within.

Section C: Observations. In these 21 passages of Section C a person relates directly to vós. They make evident the control that an individual had over voos. In 10 passages it is a psychic entity that a person can "have» or "hold" (App. One, 33-42). It is also one that he can "place» (App. One, 46-48). Someone too can "trust», «lift», «show forth", or "destroy" voos. These passages suggest the following features of voos.

(1) It can be of different kinds. On the positive side it can be 'noble', 'trustworthy', 'pure', and 'clever' (App. One, 36-37, 41-42, 46$47,53)$. On the negative side, it can be 'insatiate', 'fickle', 'harsh', or (too) 'great' (App. One, 43-44, 48, 51).

(2) Nós is very much associated with moral behaviour (App. One, $37-39,41-46,48,50,52-53$ ). It is related to justice (App. One, 37) and to its opposite, pride (App. One, 43, 48, 50).

(3) In these passage the "hidden" nature of voos is very evident (App. One, 34-35, 38-39, 41-42, 46, 51). The possibility that outer behaviour conceals a voos of quite different persuasions is a very real one and a potential source of pain for others.

(4) Once again voos is closely associated with a person's disposition or character (App. One, 37-39, 43, 45-46). His deepest personal qualities seem closely connected with this psychic entity. It functions too as a seat of his feelings of affection or otherwise for another person (App. One, 34-35, 38-39, 46).

Section D. A Person Is Described in relation to voos.

In 10 passages a person is spoken of specifically in relation to vós. In three of these, a person's relation to vós is positive. At Sol. 27,13 W. someone in his seventh and eighth group of seven years is called "best in voos and tongue." For fourteen years he flourishes mentally and verbally. Here, as in passages discussed above ${ }^{77}$, voos and tongue are associated. In this instance the excellence of both seems to be present ${ }^{78}$.

At 542,2 Simonides begins the Scopas poem: «for a man to be truly good, fashioned without fault in hands, feet, and voos, four-square, is

${ }^{71}$ See above on Theog. 1185 (App. One, 7) with note 32.

78 Contrast Theog. 1185 (App. One, 7) where he says that "few are stewards" of both tongue and voos. 
difficult ${ }^{79} . "$ Simonides draws upon a Pythagorean image of the square to indicate the perfect person. $\mathrm{He}$ is so in hands, feet, and voos. The three aspects chosen recall $I l$. XV 641-643 where Periphetes is described as excellent in feet and vós. As we have seen above, particularly in Section C, vós is connected with moral character. Here too Simonides treats it as a location of someone's moral disposition. As he says in the rest of the poem, only the gods can make the achievement of goodness possible; the most man himself can accomplish on his own is «willingly to do nothing shameful» $(542,11-40)$. But «being good», when it does happen in someone, occurs in voos and body. The degree to which a person is identified with his vóos is made clear in these lines. In another poem, epigram 26A P. $(=85,4$ D.), Simonides specifically praises Archedice for her relation to vóos: «she, being daughter, sister, wife, and mother of tyrants, was not lifted up (alpw) in voos to arrogance»" (draotaA $(\eta)$. We have seen above the association of voos with satiety and hybris ${ }^{80}$. In the present case, although there may have been great cause, Archedice did not become proud or haughty. Nós in this passage appears to be the seat of her moral character.

In four passages of Section D, a person's relation to vóos is negative. At 130,1-5 W. Archilochus describes how easily the gods raise up someone who has fallen or knock an upright individual down. In the case of the latter, the victim "roams in need of a livelihood, unhinged (mapropos) of voos". The adjective napropos is found twice in Homer, meaning 'sprawling' or 'flighty' in thought (Il. VII 156, XXIII 603). In this passage of Archilochus vós seems unable to function well. The gods have damaged the man's power to think, judge, or make choices. These lines illustrate the importance of voos as the psychic entity that allows him, if it is working well, to cope with the problems he faces.

At 223 Theognis says that the individual who thinks that he alone is wise and that his neighbour knows nothing «is foolish ( $\left.\alpha_{\phi \rho \omega v}\right)$,

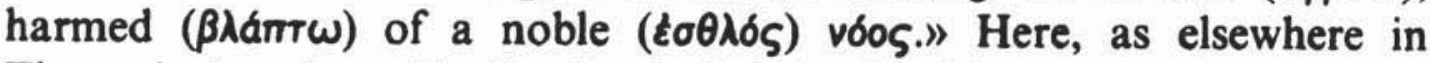

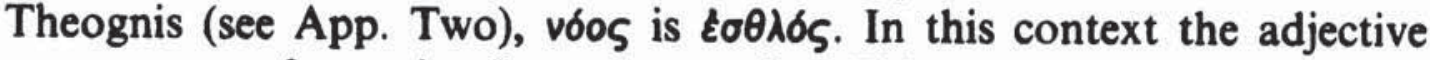
appears to refer to intellectual capacity. This voos lacks good judgement, having been «harmed» or «injured" in some way ${ }^{81}$.

79 On this passage see the remarks of Campbell, Lyric Poetry (note 20), p. 386, Gerber, Euterpe (note 20), pp. 319-320, and Fowler (note 20), pp. 84-85.

${ }^{80}$ See on Sol. 6,4 W. (App. One, 11) with note 38. On this passage see too Page, Further Greek Epigrams (note 20), p. 239.

${ }^{81}$ Cf. also Theog. 705 (App. One, 79) where Persephone harms voos. On the genitive with $\beta \lambda d \pi T \omega$, see Garzya (note 20), p. 173, and van Groningen (note 20), p. 87. 
At 1025 Theognis says that the "worthless $(\delta \varepsilon เ \lambda \circ i)$ in evil times

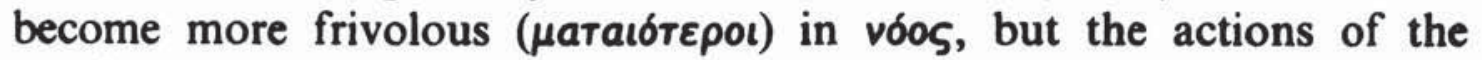
good are straighter.» The way in which evil people relate to voos appears to be ever "flighty" or "frivolous» but in evil times it becomes even more so. As we heard above at Theognis 397 (App. One, 17), vóos does not follow "worthless people in good or evil situations". In the present passage the relationship of person to voos is described as one permanently marred.

In 480 Theognis says that the individual who "passes the measure of

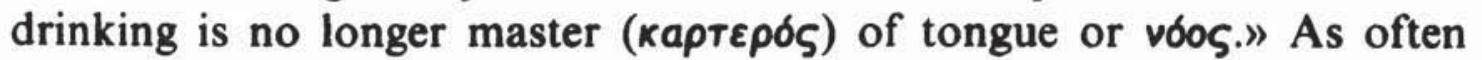
above, we have here a connection of tongue and voos ${ }^{82}$. Speech, thought, and will are all adversely affected by wine ${ }^{83}$. A man cannot control what he is thinking or saying under its influence.

In the final three passages of Section $D$, the expression «according to (katá) my vóos" is found ${ }^{84}$. First, at lines $133-142$ Theognis contrasts mortals and the gods. The former act without knowing the «end» ( $T \varepsilon \hat{\lambda}$ 오) of their activities and often the unexpected happens (133-138). They are held in the «limits of helplessness" (139). "As human-beings, we think vain things (да́тaı), knowing nothing. The gods bring all things to completion ( $\tau \varepsilon \lambda \circ \tilde{\sigma} \sigma \iota$ ) according to their vós.) This passage recalls Sem. 1,3 W. (App. One, 3) where Zeus was described as holding

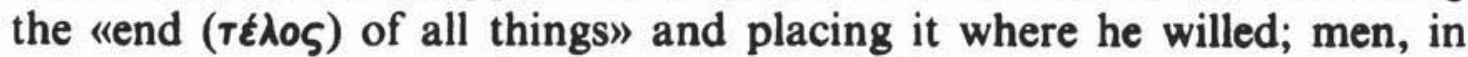
contrast, have no vós. In this passage of Theognis voos appears to be the seat of the gods' thoughts, plans, and will. Whatever their vós wishes, they can complete ${ }^{85}$. In human-beings voos may likewise be the seat of their plans and intentions but the "end" does not lie in their control. As Theognis said also in 202 (App. One, 13), "the voos of the gods prevails», so here its unavoidable nature is made clear.

The "completion" of something according to voos is mentioned also at lines 341-350. Theognis asks Zeus to "complete» ( $\tau \varepsilon \lambda \varepsilon \omega)$ his prayer in which he asks for some good fortune for himself and vengeance on his enemies. He requests: "a good divinity ( $\delta a i \mu \omega v)$ who would complete ( $\tau \varepsilon \lambda \varepsilon \hat{\omega}$ ) these things according to my vóos." Theognis' wishes, desires, and hopes for the future are to be found in his voos. The com-

${ }^{82}$ For other instances see on Theog. 1185 (App. One, 7) above with note 32.

${ }^{83} \mathrm{Cf}$. Hes., fr. 239,3 where wine «binds feet, hands, tongue, and vós in bonds.» See too below Theog. 498, 500, and 507 (App. One, 72-74) where wine likewise affects voos.

84 This expression is found also in Hom., Il. IX 108.

${ }^{85} \mathrm{Cf}$. the passages in Homer and Hesiod where vós is completed: Il. XXIII 149, Od. XXII 215, H. Her. 10; Hes., Theog. 1002. In the last two instances it is Zeus' voos that is "completed". 
pletion of these, however, is not in his control (as we heard also at 142). But, if some "divinity» were to want the same, his prayer would be fulfilled.

At Scol. 908,2 this view is expressed: «the man who does not betray his friend has great honour among mortals and gods, according to my vóos." Here vóos appear to be the location of someone's opinion or attitude. In this case it is involved in a moral judgement.

Section D: Observations. In these 10 passages some relationship between person and voos is indicated. This can be positive: «best» or "good" in vóos (App. One, 54-55). Or negative: «unhinged" of vóos, "frivolous» in vóos, or "not master» of it (App. One, 56, 59-60). Certain features of vós are again evident. Intellectual activity is centered in it (App. One, 54, 58, 60, 61-63). It is associated with moral character and judgements (App. One, 55, 59, 63). It acts as the seat of a person's attitudes, wishes, and opinions (App. One, 61-63). It is strongly connected with the disposition and temperament of an individual (App. One, 5556, 58-59).

\section{Section E. Outside Objects Affect vós.}

In 11 passages the lyric poets speak of outside forces that affect vóos directly. These passages show how vulnerable vós could be to outside influences. The boundaries of this psychic entity were not strictly defined. It could be altered from without.

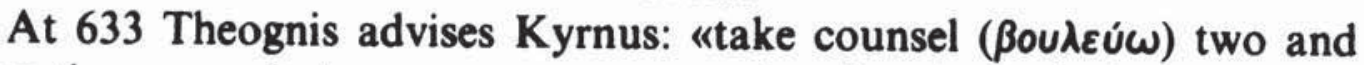

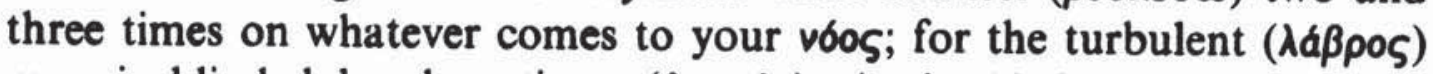
man is blinded by deception" (armpós). As in 1052 (App. One, 30), where Kyrnus was to "take counsel with his good voos", here too Theognis associates this activity with vóos. As mentioned in the Introduction, Homer often connects vós with 'counsel' (see note 4). Whatever thoughts, ideas, or suggestions come to voos are to be scrutinized. Otherwise, 'deception' becomes a strong possibility. At 1054 (discussed above with 1053, App. One, 20), Theognis similarly praises the value of

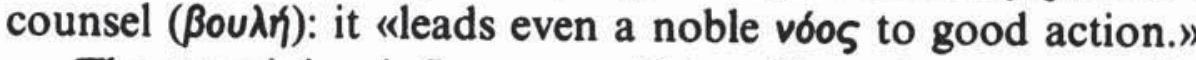

The remaining influences said to affect voos are negative in nature. At $124 \mathrm{~b} \mathrm{~W}$. Archilochus teases a friend who came uninvited to a ban-

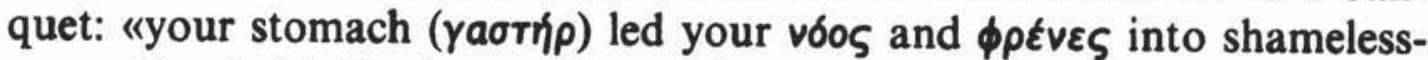
ness" (avai $\delta \varepsilon i \eta)$. Both psychic entities are associated here with desires that led to socially unacceptable behaviour." This person did not show good judgement in this situation. 
At 5,7-8 Mimnermus vividly describes the effects of old age: «hateful and dishonoured, it makes a man unrecognisable and, being poured around, it harms ( $\beta \lambda a ́ m \pi \omega)$ eyes and vóos." The image here seems to be that of old age "clouding" or "veiling" vóo ${ }^{86}$. When this occurs, the "inner vision» of voos seems to be damaged. In this passage vós functions as a seat of intellectual activity, one harmed by time. In our discussion of Sim. 8,1-10 W. (App. One, 4) and Sol. 27,11 and $13 \mathrm{~W}$. (App. One, 21, 54), we saw how vóos changes with time. Unfortunately in old age it suffers injury.

At 202 above (App. One, 13), we heard that the «gods' voos prevails": the person attaining unjust wealth is finally punished. At 203 Theognis says: "this deceives (anatáw) the vóos of men", namely that the gods do not punish unjust persons instantly. Here vóos can be "deceived". Homer and Hesiod likewise speak of the deception of vó ${ }^{87}$. In this case vós fails to "see» the way in which the gods act. As a result, it apparently encourages a person to abide in unjust behaviour, which brings inevitable punishment.

In another passage, 629-630, Theognis laments the effects of a parti-

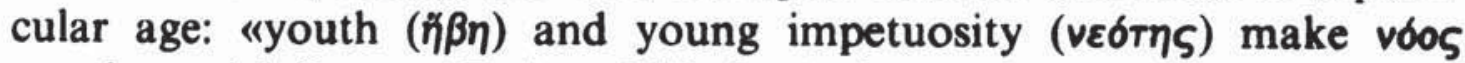
unsubstantial ( $\varepsilon \pi \kappa o u \phi i \zeta \omega)$ and lift $\theta u \mu \delta \zeta$ into error ( $\alpha \mu \pi \lambda a x i a)$ in many things.» Like Homer who twice mentions the adverse influence of youth on voos (Il. XXIII 590, 604), Theognis notes its "trivializing" effect. We heard above of the "koöфos vós of an evil man" at Theog. 580 (App. One, 44) ${ }^{88}$. Wine too will make vóos such (Theog. 498, App. One, 72). As in the situation where one "destroys his vóos" (Theog. 36, 1271, App. One, 52-53), here youth somehows damages the judgement and valuable thoughts that his voos may be capable of expressing. Also affecting $\theta u \mu \delta \varsigma$ adversely, it may lead to immoral behaviour. This passage, like so many others, may associate voos with such negative moral actions.

Theognis speaks of three other forces that negatively affect voos. First, he describes "necessity». At 193-196, in mentioning a man who

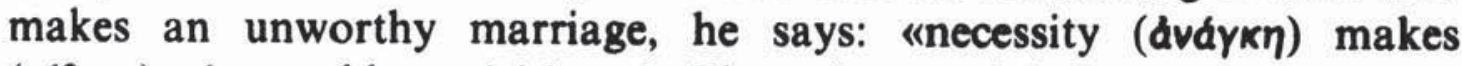
$(\tau i \theta \eta \mu \iota)$ vóos reckless" ( $\tau \lambda \dot{\eta} \mu \omega v)$. The values and judgements that vóos may normally express are distorted by «necessity». This leads voos to make choices that it otherwise would not. Nós thus proves vulnerable to unfavourable outside circumstances.

${ }^{86} \mathrm{Cf}$. the uses of the verb $\alpha \mu \phi(x \in \omega$ with "sleep" and "grief» in Homer (Il. XIV 252 and $O d$. IV 716).

87 See Il. XIV 160; H. Apoll. 379; Hes., Theog. 537, W. \& D. 323, 373.

${ }^{88}$ See further on koOфos above on Sim. 8,1-10 W. (App. One, 4) with note 29. 
Second, he mentions poverty. At $649-652$ he asks of it: "why do you

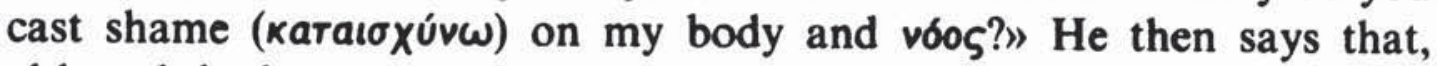
although he knew «noble and good things", poverty taught him «many shameful actions». Here the connection of voos with moral behaviour is quite apparent. Poverty, like necessity, leads the person to considerations he would not otherwise entertain, ones alien to the way he thought and judged before ${ }^{89}$. It involves him in "shameful actions», originating, it seems, from his voos.

Three times Theognis speaks of wine affecting voos. At 498 he describes it as «making ( $(\dot{\theta} \eta \mu)$ ) the voos of the wise and foolish man unsubstantial» (коüфos). It negatively affects a person's ability to think and to judge. His mind is "trivial». "Youth" had the same effect upon vós, as we heard above at 629 (App. One, 69) ${ }^{90}$. At 500 Theognis says further of wine that it serves like fire for silver and gold to "show ( $\delta \varepsilon i$ ikvupi) the voos of a man.» He then says that it can "disgrace even the wise man.» This passage may suggest the «hidden» nature of vóos. Wine brings it to light. Perhaps the wise person, in particular, keeps his innermost thoughts concealed, but wine can reveal these and sometimes the revelation is a negative one. At 507-508 he further describes wine as "holding $(\varepsilon \chi \omega)$ his feet and the voos in his chest»"1. In this condition he fears that he may do something that will bring «reproach". Wine, removing good judgement and clear thinking, has the power to make the person behave in an unacceptable manner. Once again, the association of voos with moral behaviour seems evident here.

Section E: Observations. In these 11 passages of Section E we see the ways in which vóos can be affected by outside forces. Most of these forces are negative: old age, e. g., youth, necessity, poverty, and wine. Certain aspects of voos are prominent in these occurrences. It is associated with intellectual activity (App. One, 64-65, 67-79). It is connected with moral behaviour (App. One, 66, 69-71). Its «hidden» nature too may have been indicated (App. One, 73). Noos is very much a changeable entity that unfortunately can be altered for the worse.

Section F. Outside Agents Affect vóos.

In 8 passages outside agents, mainly the gods, can influence vóos. Like the passages in Section E, these show how open to outside influences vóos can be.

${ }^{89}$ See the discussion of these lines in van Groningen (note 20), pp. 257-258.

${ }^{9}$ See further on ko0 $\$$ S 5 above on Sim. 8,1-10 W. (App. One, 4) with note 29.

9 "Cf. Hes., fr. 239,3 where "wine binds feet, hands, tongue, and vós in bonds". 
In 6 passages the gods affect the voos of human-beings. We have heard above that the gods can «know what sort of voros each person has» and that Zeus "knows» well the voos of each individual (Theog. 898, 375, App. One, 23-24). The gods can also cause a man to wander "unhinged of vós" (Arch. 130,5 W., App. One, 57). At 96,1 W. Archi-

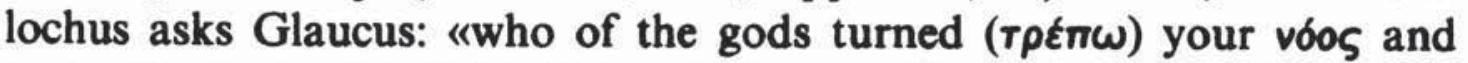
фpeves?» As in Od. XIX 479 and Theog. 379 (above, App. One, 22), vóos can be "turned». Some change in its functioning results.

At 7,1 W. Semonides begins his poem on women by saying: «god

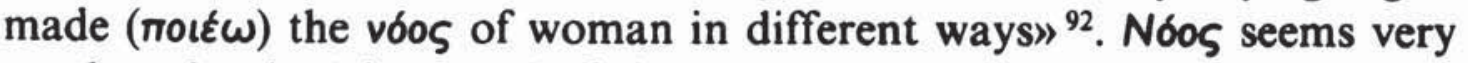
much to be the 'character' of these women, who reveal their nature by their origin from several different animals ${ }^{93}$. Nóos acts as the seat of their personality traits and their ways of thinking ${ }^{94}$. In the case of these women vós seems to indicate permanent facets of personality. Although their behaviour may change from day to day, their vós has some specific qualities that makes their overall way of acting predictable. At a deep level this vós does not appear to change.

At 42 W. (= Sim. 525), Semonides also says ${ }^{95}$ : «the gods easily steal ( $(\lambda \hat{\varepsilon} \pi T \omega)$ the vóos of men.» In Homer Zeus can 'bewitch' $(\theta \varepsilon \hat{\lambda} \gamma \omega)$ the vós of men (Il. XII 255). In this fragment of Semonides they seem to be able to remove the ability that human-beings have to think or to

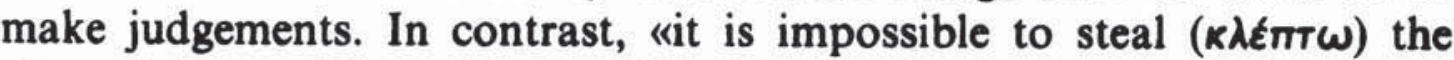
vóos of Zeus» (Hes., Theog. 613). Man's voos is vulnerable in a way that a god's is not.

Theognis mentions the influence of the gods on vós in two passages. At 760 , in order that he may sing a «holy song», he prays: «may Apollo guide astraight ( $\delta p \theta \delta \omega)$ my tongue and vós." Here again, as in passages treated above, vós and tongue are connected ${ }^{96}$. In this situation the gods can have a positive influence upon thought and speech. The verb $\delta \rho \theta \delta \omega$ may suggest some moral involvement on the part of vóos: what he thinks or says will be free from fault ${ }^{97}$. At 705 Theognis describes Persephone as one who "gives forgetfulness $(\lambda ; \theta \eta)$ to mortals, harming ( $\beta \lambda a ́ m \pi \omega)$ their vóos.» Here vós is called the seat of memory.

92 On this poem of Semonides see H. Lloyd-Jones, Females of the Species, London 1975; W. J. Verdenius, "Semonides über die Frauen», Mn 21, 1968, pp. 132-158, and «Epilegomena zu Semonides Fr. 7", Mn 30, 1977, pp. 1-12.

${ }^{93} \mathrm{Cf}$. Hes., $W . \&$ D. 67 where he describes Hermes as placing «a shameful vóos in women".

${ }^{44}$ See Lloyd-Jones (note 92), p. 64, and Verdenius, $M n 30,1977$, p. 1.

${ }^{95}$ On the authorship of this fragment, see Renehan (note 20), pp. 8-9.

${ }^{96}$ See above on Theog. 1185 (App. One, 7) with note 32.

97 Cf. the reference in Pind., Pyth. X 68 to a "voos bpobs". 
This death harms. It can no longer recall past events. Apparently, in the living person, vós allows this activity.

In a passage ascribed to Stesichorus, $P$. Lille $76 \mathrm{abc}^{98}$, a possible restoration of 207 is «the gods put in ( $T(\theta \eta \mu l)$ another ( $\left(\mu_{0}\right)$ ) vós for each day" ${ }^{99}$. If this is correct, we have here a clear connection between vós and the "day", very similar to that found in Od. XVIII 134-137. As we have seen in other passages ${ }^{100}$, voos is a changeable entity that can vary with the "day" that it encounters. In this case a "different" vós may be put in by the gods. They have the power to alter someone's thinking and way of perceiving reality.

In a passage of Sappho, it is a person who affects the vós of another. At 57,1 she asks: «what country girl has bewitched $(\theta \varepsilon \hat{\varepsilon} \gamma \omega)$ your vós, not knowing how to draw her skirts about her ankles?» ${ }^{101}$ This country girl evidently did not know how to arrange her skirts in a decorous manner. Just like Zeus who 'bewitches' ( $\theta \dot{\varepsilon} \lambda \gamma \omega)$ the voos of the Achaians at $I l$. XII 255, this girl removes the clear thinking of the man involved. Hesiod, at $W . \& D .373$, likewise warns against the effect a woman can have upon vóos. It proves susceptible to female behaviour.

In the final passage of Section F, a drinking song, Scolion 889, poses an ideal situation. "Would that it were possible to see what each person is like by opening his chest and, having looked at his voos, to close it up again and to consider a man a friend because of his $\phi p \eta j v$ that is without deceit.» Here the "hidden" nature of voos is vividly described ${ }^{102}$. It acts as the seat of a person's real thoughts, feelings, and desires. If one could "see» these, one would know if the person was a true friend or not. In this passage voos and $\phi \rho \eta v$ appear to be synonyms. Both serve as locations of the person's actual attitudes. Only when voos is seen clearly can behaviour be considered genuine and without deceit ${ }^{103}$.

97 On this fragment see P. J. Parsons, "The Lille "Stesichorus"", $Z P E$ 26, 1977, pp. 7-36; M. L. West, «Stesichorus at Lille», ZPE 29, 1978, pp. 1-3, and M. Haslam, "The Versification of the New Stesichorus (P. Lille 76abc)", GRBS 19, 1978, pp. 2957.

99 See Parsons (note 98), pp. 21-22.

100 See above on Sem. 1,3 W. (App. One, 3) with references to other passages in note 27.

${ }^{101}$ On the text see Campbell, Greek Lyric (note 20), p. 100. On this translation see Kirkwood (note 20), p. 132. See too Fränkel (note 20), p. 208 for an explanation of these lines.

102 On the «hidden" nature of vós, see above on Theog. 121 (App. One, 21) with note 47 .

${ }^{103}$ The following fragments mentioning voos have not been treated because the context is not clear: Alcm. 104, Stesich. S 15 i 5, Alc. 43 (B 11,1), and Sim. 511 fr. 
Section F: Observations. In 6 passages of this Section, the gods affect vóos in some way. They can act positively (App. One, 78) but most often their influence is negative (App. One, 75-77, 79-80). Nóos proves very susceptible to their actions. Its intellectual activity is adversely affected. These passages show us two important features of voos: it is "hidden" (App. One, 82) and it is the seat of memory (App. One, 79).

\section{Conclusion}

The above analysis of vóos in all the lyric poets except Pindar and Bacchylides illustrates the range of meaning of this psychic term. It also shows how a person relates to the voos within him. In this analysis we divided the relevant passages into six Sections. Section A treated passages in which vós was present, active, or «known» in a person. This Section illustrated some of the range of independent activity that voos could carry on in a person. It also showed certain qualities which vós could have and ways in which it was recognised by others. These passages where vóos was «known» suggest its importance as a seat of a person's true nature or character. Section B, in which a person used or acted with voos, contained only three passages. Although the fragmentary nature of the evidence must be borne in mind, these few passages do suggest that vós was not often looked on as an instrument or accompaniment which someone could use or act with. Section C discussed the relationships a person could have with voos. In particular it illustrated the control a person could exert over vós. Section $D$, in which a person was described in relation to vós, showed again how closely associated an individual's character was to this psychic entity. Sections $\mathrm{E}$ and $\mathrm{F}$ described outside forces and agents that could act upon vós. These Sections illustrated how vulnerable vós was to outside influences. In no way were it boundaries fixed or defined.

The above analysis suggests certain prominent features of voos (see also the Observations at the end of each Section). First, voos occurs only in the singular. It is found, however, in all four cases. Second, in terms of placement, voos, when it is located, is to be found in the chest region (see note 41). It itself never serves as a location of other psychic entities.

4,9. This article did not treat Corinna 692 fr. 7,9 (fragmentary) and 654 i 28 ( $\tau \tilde{\omega} \delta \xi$ vó́ৎ $\gamma \varepsilon \gamma d \theta_{\imath}$ ) because her poetry is likely hellenistic. See $M$. L. West, «Corinna», $C Q$ 20,1970 , pp. $277-287$. 
Noos is a changeable entity. It appears to vary with the "day" that comes upon it (App. One, 3, 57, 80). This phenomenon helps to explain why voos in others and in oneself varies. Some types of voos, however, seem to be permanent, as, e. g., those found in the different women described by Semonides ( $7 \mathrm{~W}$., App. One, 76). There may be certain permanent traits of character located in vós. But in other passages it seems that, even when vóos has in essence some positive nature, the person himself or outside forces can alter it (App. One, 37, 52-53, 70 72). Nós too changes with the age of the person. Youth can make it «frivolous» (App. One, 69). Hopes also seem to distort it, especially in the young person (App. One, 3-4). In the middle years it grows stronger and flourishes (App. One, 21, 54). Old age harms it (App. One, 67). During a person's lifetime various forces can alter vós for the worse (App. One, 66-77). Wine in particular affects it adversely (App. One, $60,71-74)$. It is especially vulnerable also to the action of the gods (App. One, 75-80).

In terms of activity voos seems involved in a whole range of psychological functions: intellectual, emotional, and volitional. When intellectual activity is prominent, it often seems associated with «inner vision» or with some perception that a person has on a deep level (App. One, $5,15,31,40,67-68$ ). It functions too as a seat of memory (App. One, 79). It may act as well as a location of imagination (App. One, 33). It is quite often connected with the tongue (App. One, 7, 15, 32, 39, 51, $54,60,78)$. The ideal seems to be for speech and voos to be in accord but this does not appear frequently to be the case. Nós does not seem strongly associated with emotion, but in some passages it functions as a location of the attraction or affection that one feels for another (App. One, 33, 38, 46, 81). In terms of volition, vós is often associated with the desires and plans someone may express (App. One, 13-14, 22, 30, $33,38-40,48,51,61-65)$.

To a very large degree vóos functions as the seat of a person's character or temperament. His deepest qualities appear to be found in vós. He identifies most closely with this psychic entity. Person and vós appear to be in harmony. Although he can exert control over vós, he still seems most often to be in accord with it. Person and vós remain distinct but in large measure vóos acts as the seat of someone's disposition and traits of personality. There his inner nature is to be found ${ }^{104}$.

104 Some passages illustrating this aspect of 5605 include the following: App. One, 20, 22, 25-29, 37, 54-55, 71, 73. See also the Observations at the end of each Section. 
Within the person vóos displays certain qualities. These are indicated in particular by the descriptive adjectives qualifying this psychic term (see App. Two). These adjectives show especially how closely a person's moral character was related to vós. The description could be positive: 'trustworthy', 'good', 'noble', or 'pure' (see App. Two). Or it could be negative: 'unjust', 'empty', 'not fitting', 'false', 'insatiate', 'flighty', or 'harsh' (see App. Two).

One striking feature of vóos in these poets is its relation to moral behaviour (see, e. g., App. One, 14, 19-20, 55, 59, 63). Within the person it is very much the well-spring of his inclination to justice (App. One, 16, 22-24, 37, 56). It can also be involved in unjust actions, sometimes related to satiety and hybris (App. One, 5, 9, 11, 22, 48, 64). When it is called 'good' or 'noble', vós appears in itself to have a positive moral capacity (see App. Two). But this capacity too can be altered or destroyed (App. One, 37, 52-53, 70-71). Other adjectives as well emphasize the moral aspect of vóos: 'trustworthy' and 'pure', e.g., or 'insatiate' and 'harsh'.

Another striking feature of vós within the individual is its "hidden» nature. It acts as the location of a person's true feelings and thoughts and, as such, abides somehow deep within the individual, far out of reach of the gaze of others (App. One, 1, 15, 18, 26-28, 34-35, 73). Someone's behaviour can reflect this vóos and this situation is most desirable (App. One, 8, 51). But behaviour too can fail to be in accord with voos and may, in fact, be in direct conflict with it (App. One, 8, $18,34-35,46,82$ ). A person, it appears, may intentionally hide his vó to protect himself. To know, therefore, what another person is actually thinking may require some examination (App. One, 34-35). Theognis at 499-500 refers to wine as the test for showing what voos is really like. It brings voos to the surface, so to speak, and makes it apparent. What it reveals may not always be welcome.

In the lyric poets, as in Homer, Hesiod, and the Homeric Hymns at an earlier time, voós seems best described as a «faculty capable of a number of psychological activities». It often signifies a "way of thinking" that a person has or the attitudes or opinions that he holds. But in the lyric poets, even more than in the earlier authors, it functions as a seat of disposition, temperament, and character. Moral traits especially seem prominently associated with it. Here we must bear in mind two points. The nature of this lyric poetry itself with its particular concerns may affect how vóos is pictured. Thus, with Theognis, e. g., moral exhortation forms a strong component of his verses. We must always remember too the fragmentary nature of the evidence we are 
examining. But what we can say, from the poetry we do possess, is that vóos sums up a person best. It is this psychic entity that we should seek out in others, if we wish to know their true attitudes and thoughts. It is in this psychic entity that the individual finds himself most authentically expressed.

\title{
Shirley Darcus Sullivan
}

\author{
APPENDIX ONE \\ voos in the Greek Lyric Poets \\ (excluding Pindar and Bacchylides)
}

Section A: vóos as Present, Active, or «Known» in a Person.

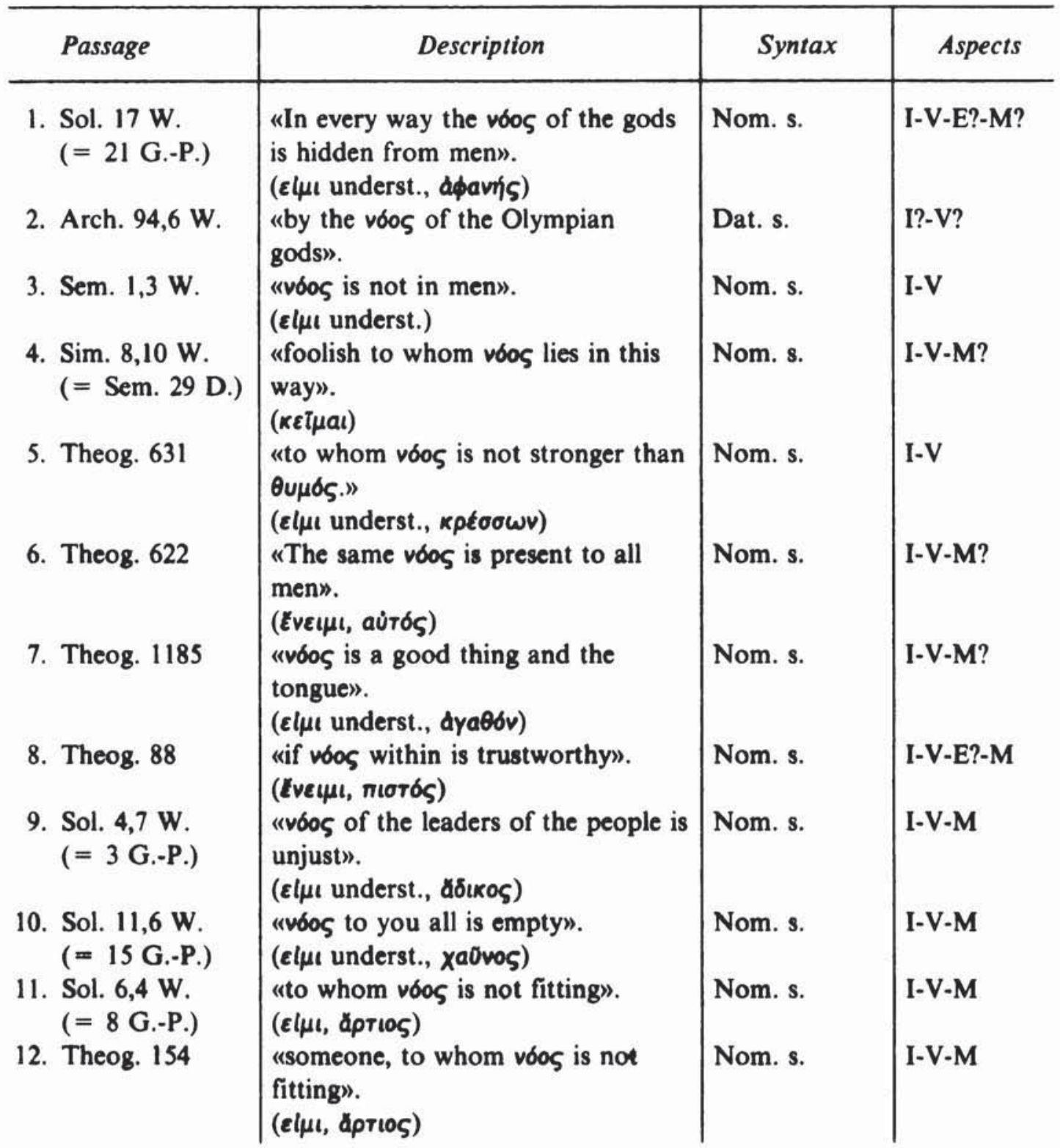




\begin{tabular}{|c|c|c|c|}
\hline Passage & Description & Syntax & Aspects \\
\hline 13. Theog. 202 & 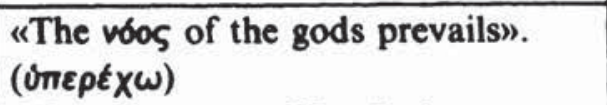 & Nom. s. & I-V-E?-M \\
\hline 14. Theog. 377 & $\begin{array}{l}\text { "How does your [Zeus] voos } \\
\text { endure to hold in the same esteem } \\
\text { sinners and the just man?" } \\
\left(\tau 0 \lambda \mu d \omega, E_{X}(\omega)\right.\end{array}$ & Nom. s. & I-V-E?-M \\
\hline 15. Theog. 1163 & $\begin{array}{l}\text { «Eyes, tongue, ears, and wos grow } \\
\text { in the chests of the wise». } \\
(\phi \dot{v} \omega)\end{array}$ & Nom. s. & I.V V \\
\hline 16. Theog. 395 & 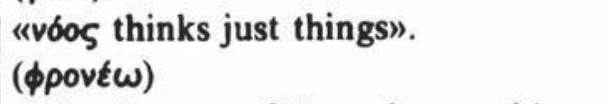 & Nom. s. & I-V-M \\
\hline 17. Theog. 397 & $\begin{array}{l}\text { «vós does not follow the worthless } \\
\text { person in good or evil situations". } \\
\text { (Ennouai) }\end{array}$ & Nom. s. & I-V-M \\
\hline 18. Theog. 121 & 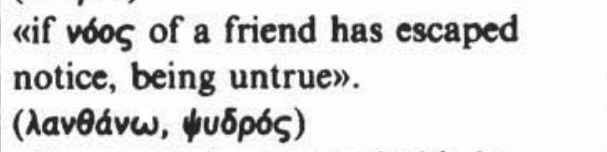 & Nom. s. & I-V-E-M \\
\hline 19. Theog. 686 & $\begin{array}{l}\text { "Some people, money holds in } \\
\text { check, others, voos". } \\
(\varepsilon \text { lp } \omega)\end{array}$ & Nom. s. & I-V-M \\
\hline 20. Theog. 1053 & $\begin{array}{l}\text { "The } \theta u \mu \delta \varsigma \text { and voos of the foolish } \\
\text { flutter about". } \\
\text { (nEтонаı) }\end{array}$ & Nom. s. & I-V \\
\hline $\begin{array}{l}\text { 21. Sol. } 27,11 \mathrm{~W} \text {. } \\
(=23 \text { G.-P. })\end{array}$ & $\begin{array}{l}\text { "vós is strengthened». } \\
\text { (катартúw) }\end{array}$ & Nom. s. & I-V-M \\
\hline 22 Theog. 379 & 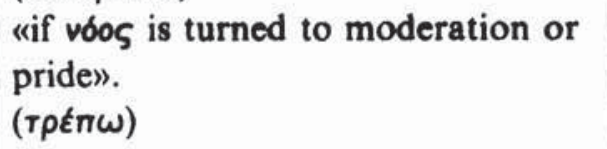 & Nom. s. & I-V-E?-M \\
\hline 23. Theog. 898 & 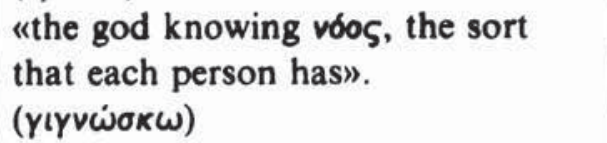 & Acc. s./d.o. & I-V-E?-M \\
\hline 24. Theog. 375 & 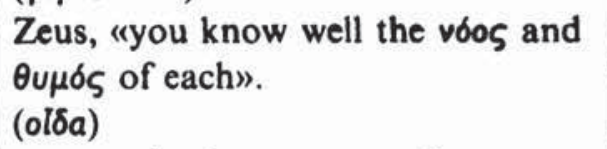 & Acc. s./d.o. & I-V-M \\
\hline 25. Theog. 598 & $\begin{array}{l}\text { «man, who knows your voos } \\
\text { better». } \\
\text { (oløa) }\end{array}$ & Acc. s./d.o. & I-V-E?-M \\
\hline 26. Theog. 125 & 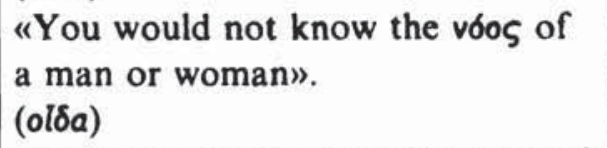 & Acc. s./d.o. & I-V-E?-M \\
\hline 27. Theog. 367 & 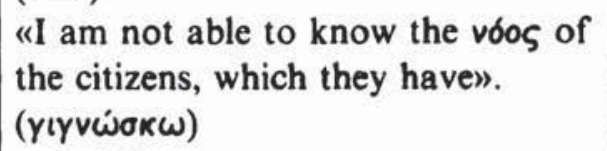 & Acc. s./d.o. & I-V-M \\
\hline $\begin{array}{l}\text { 28. Theog. } 1184 \text { a } \\
\text { 29. Theog. } 439\end{array}$ & $\begin{array}{l}\text { as in } 27 . \\
\text { «foolish is he who holds my vós } \\
\text { under surveillance». } \\
(\varepsilon \times \omega \varepsilon v \phi u \lambda a k \not ̋ \sigma เ v)\end{array}$ & $\begin{array}{l}\text { Acc. s./d.o. } \\
\text { Acc. s./d.o. }\end{array}$ & $\begin{array}{l}\text { I-V-M } \\
\text { I-V-M }\end{array}$ \\
\hline
\end{tabular}




\begin{tabular}{l|c|c|c}
\hline Passage & Description & Syntax & Aspects \\
\hline
\end{tabular}

Section B: Person Acts in, by, or with voos.

30. Theog. 1052

31. Theog. 1237

32. Theog. 365
"Take counsel with your deep $\phi p r \eta$ and good vóos". (ßouleúw, dyaقós) "Strive to understand a saying with your vóos". (ouvopáw) "Check yourself in your voos". $(\boldsymbol{\varepsilon} \times \boldsymbol{\omega})$

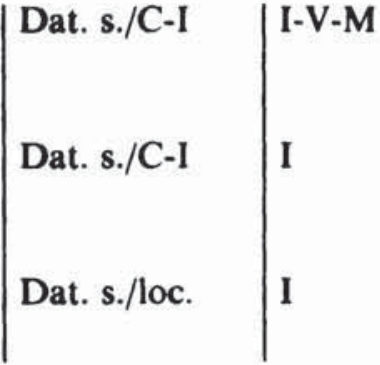

Section C: A Person Has a Direct Relationship with voos.

33. Sa. 96,2

34. Theog. 1016

35. Theog. 814

36. Arch. $185,6 \mathrm{~W}$.

37. Theog. 792

38. Theog. 87

39. Theog. 91

40. Theog. 461

41. Theog. 74

42. Theog. 698

43. Theog. 109

44. Theog. 580 "holding vóos in this direction often".

$(\boldsymbol{E} \times \omega)$ "to test friends, what vóos they have". $(\varepsilon \xi \varepsilon T d \zeta \omega, \varepsilon \times \omega)$ "I will know of my enemies, what voos they have". (olda, Exw)

fox, «having a cunning vós").

(Exw, nukvós) "and among the good may I have a noble vóos". $(\varepsilon \times \omega, \varepsilon \sigma \theta \lambda \sigma \xi)$ "do not hold vós and $\phi p \varepsilon v e s$ in another direction".

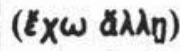
"who holds voos in two ways with one tongue».

( $k x \omega)$ «Do not hold vós on impossible deeds". ( $k$ x $w)$ "Few have a trustworthy vóg".

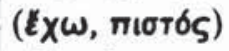
"Few have a trustworthy vóos".

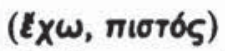
«Evil persons have an insatiate vóos".

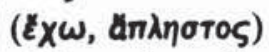

«I hate the evil man who has the unsubstantial voos of a small bird". (Exw, ko0фos)

\begin{tabular}{l|l} 
Acc. s./d.o. & I-E \\
Acc. s./d.o. & I-V-E?-M \\
Acc. s./d.o. & I-V-E?-M \\
Acc. s./d.o. & I \\
Acc. s./d.o. & I-V-E?-M \\
Acc. s./d.o. & I-V-E \\
Acc. s./d.o. & I-V-E-M \\
Acc. s./d.o. & I-V-E \\
Acc. s./d.o. & I-V-E?-M \\
Acc. s./d.o. & I-V-E?-M \\
Acc. s./d.o. & I-V-E-M \\
Acc. s.o. & I-V-E?-M \\
A-V. &
\end{tabular}




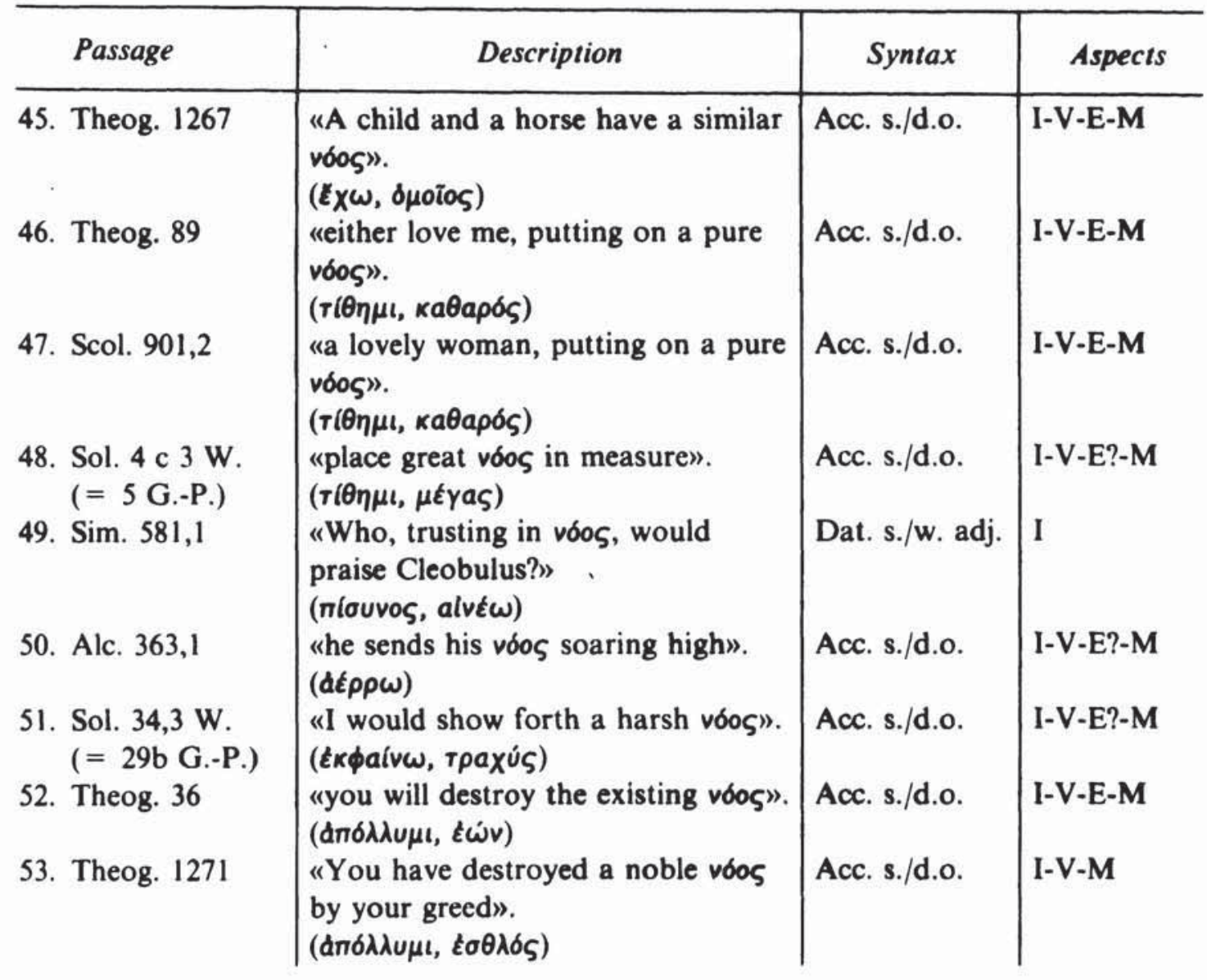

Section D: A Person Is Described in relation to vós.

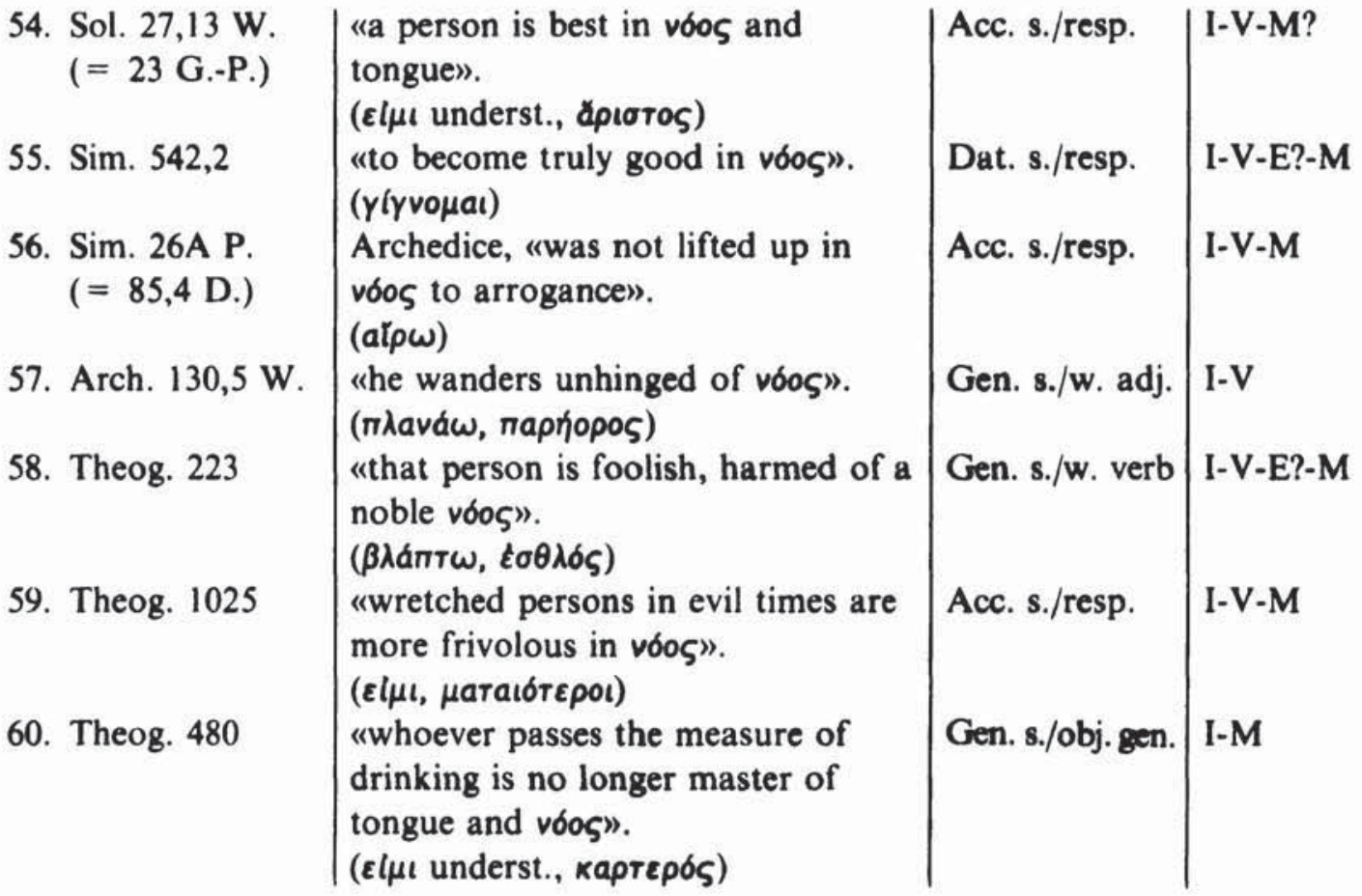




\begin{tabular}{|c|c|c|c|}
\hline Passage & Description & Syntax & Aspects \\
\hline 61. Theog. 142 & $\begin{array}{l}\text { "Gods complete everything } \\
\text { according to their vóos". } \\
(\tau \varepsilon \lambda \hat{\varepsilon} \omega)\end{array}$ & Acc. s./katá & I-V-M \\
\hline 62. Theog. 350 & $\begin{array}{l}\text { "a divinity who would complete } \\
\text { these things according to my vós". } \\
(\tau \varepsilon \lambda \epsilon \omega)\end{array}$ & Acc. s./katá & I-V-M \\
\hline 63. Scol. 908,2 & $\begin{array}{l}\text { "he has honour according to my } \\
\text { vó̧". } \\
(\varepsilon \chi \omega, \tau \mu \eta \tilde{\eta})\end{array}$ & Acc. s./кatá & I-V-M \\
\hline
\end{tabular}

Section E: Outside Objects Affect vóos.

64. Theog. 633

65. Theog. 1054

66. Arch. 124 b W.

67. Mim. 5,8 (= 1 G.-P.)

68. Theog. 203

69. Theog. 629

70. Theog. 196

71. Theog. 650

72. Theog. 498

73. Theog. 500

74. Theog. 507

\begin{tabular}{|c|}
\hline 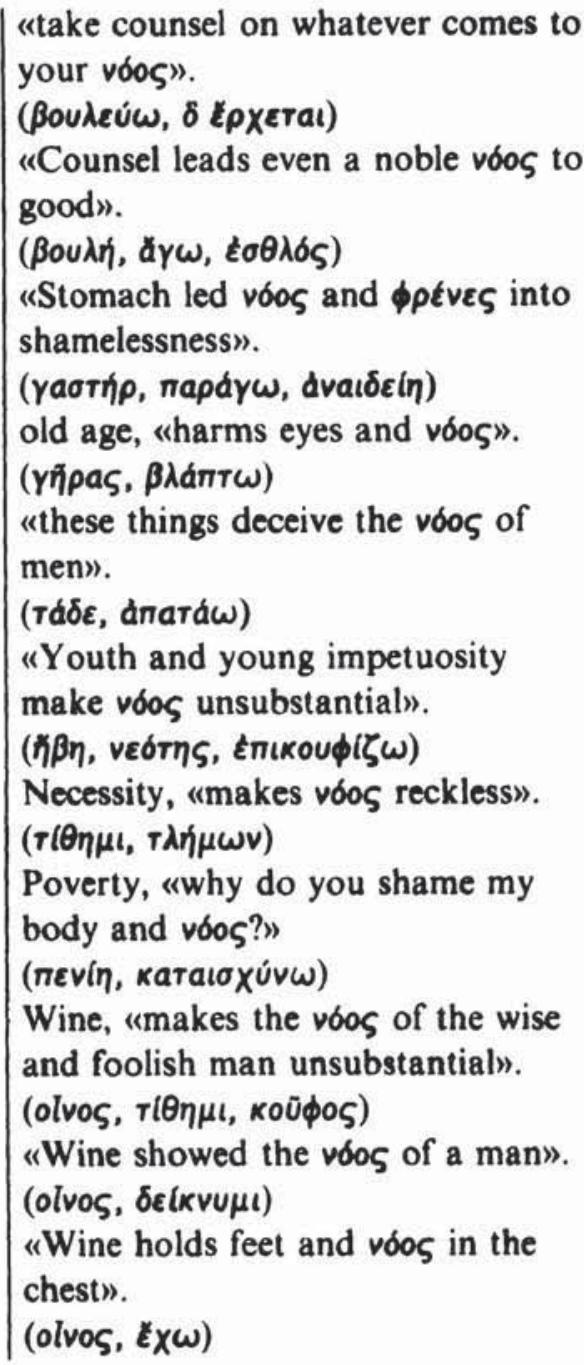 \\
\hline
\end{tabular}

\begin{tabular}{|l|l} 
Acc. s./tmi & $I$ \\
Acc. s./d.o. & I-V-M \\
Acc. s./d.o. & E-I \\
Acc. s./d.o. & $I$ \\
Acc. s./d.o. & I-V \\
Acc. s./d.o. & I-V-M \\
Acc. s./d.o. & I-V-E?-M \\
Acc. s./d.o. & I-V-M \\
Acc. s./d.o. & I-V-E?-M \\
Acc. s./d.o. & I-V-M \\
Acc. s./d.o. & I-V-M
\end{tabular}

Acc. s./d.o. I-E-V

Section F: Outside Agents Affect voos.

75. Arch. 96,1 W. "Glaucus, who of the gods, having turned your vóos and фpéves?» $(\tau \rho \varepsilon \pi \omega)$

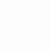

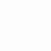




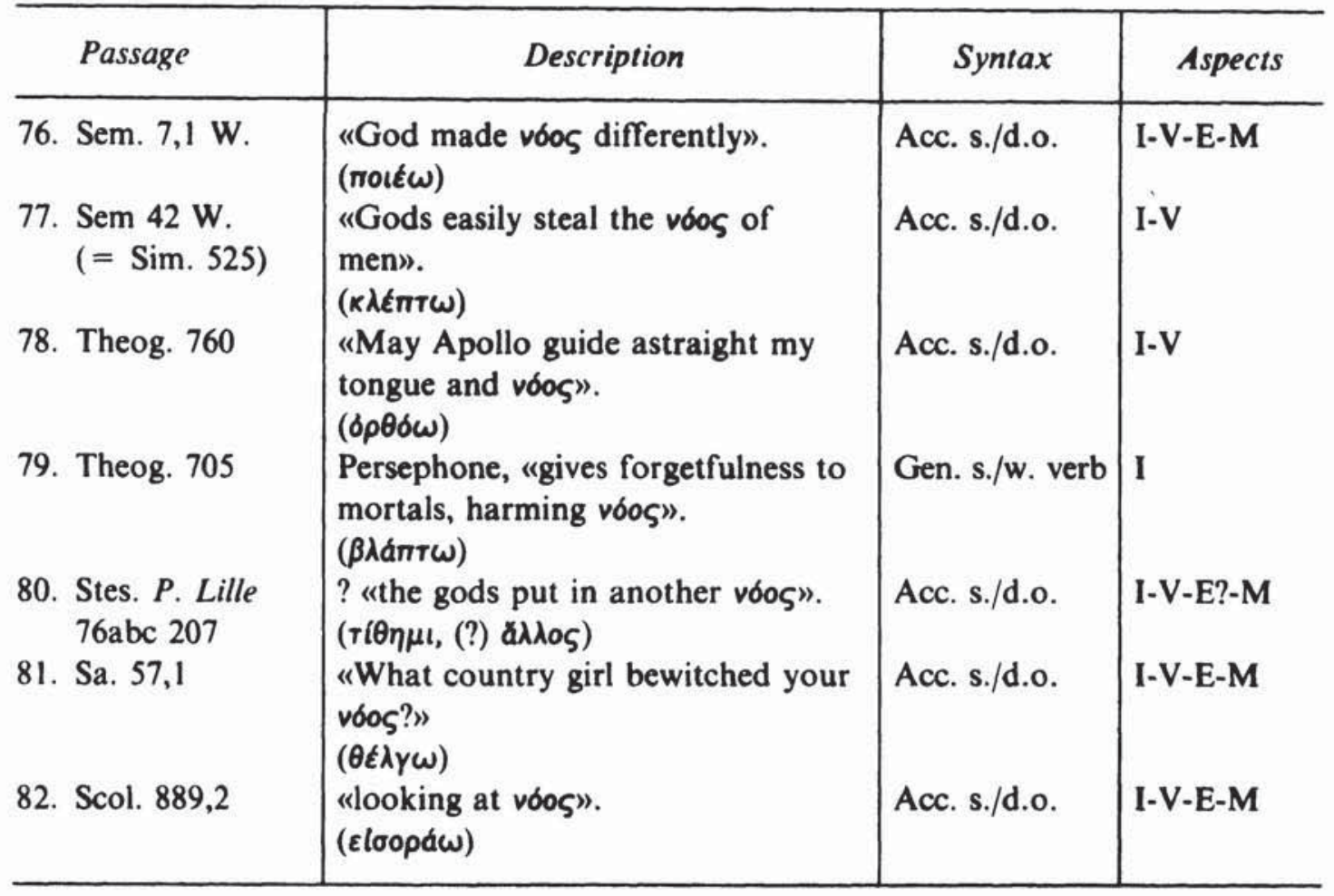

\section{APPENDIX TWO}

Descriptive Adjectives with voos

\begin{tabular}{|c|c|c|c|}
\hline Passage & App. One & Adjective & Meaning \\
\hline Theog. 1052 & B. 30 & dyaeós & 'good', 'noble'. \\
\hline Sol. $4,7 \mathrm{~W}$. & A. 9 & a $\delta$ ikos & 'unjust', 'wrong-doing'. \\
\hline $\begin{array}{l}\text { Stes. } P \text {. Lille } \\
\text { 76abc } 207\end{array}$ & F.80 & (?) $\mathrm{a} \lambda \mathrm{AOS}_{\mathrm{S}}$ & 'other', 'another'. \\
\hline Theog. 109 & C. 43 & 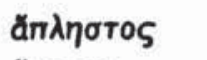 & 'insatiate', 'not to be filled'. \\
\hline Sol. $6,4 \mathrm{~W}$. & A.11 & ăprios & 'fitting', 'suitable'. \\
\hline Theog. 154 & A. 12 & aprios & 'fitting', 'suitable'. \\
\hline Sol. $17 \mathrm{~W}$. & A.1 & 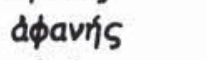 & 'hidden', 'obscure'. \\
\hline Theog. 622 & A. 6 & aủtós & 'the same'. \\
\hline Theog. 792 & C. 37 & $\varepsilon \sigma \theta \lambda o ́ s$ & 'noble', 'good'. \\
\hline Theog. 1271 & C. 53 & $\varepsilon \sigma \theta \lambda \sigma \varsigma$ & 'noble', 'good'. \\
\hline Theog. 223 & D. 58 & $\varepsilon \sigma \theta \lambda \sigma \zeta$ & 'noble', 'good'. \\
\hline Theog. 1054 & E.65 & $\varepsilon \sigma \theta \lambda \sigma \zeta$ & 'noble', 'good'. \\
\hline Theog. 36 & C. 52 & $\varepsilon \dot{\omega} v$ & 'the existing', 'the present'. \\
\hline Theog. 89 & C. 46 & каөарб́s & 'pure', 'honest', 'clean'. \\
\hline Scol. 901,2 & C. 47 & каөарб́s & 'pure', 'free from guilt'. \\
\hline Theog. 580 & C. 44 & коÕфOS & 'unsubstantial', 'empty'. \\
\hline Theog. 498 & E.72 & коÖфоS & 'unsubstantial', 'empty'. \\
\hline Theog. 631 & A. 5 & $\kappa \rho \varepsilon \sigma \sigma \omega V$ & 'stronger', 'mightier'. \\
\hline
\end{tabular}




\begin{tabular}{|c|c|c|c|}
\hline Passage & App. One & Adjective & Meaning \\
\hline $\begin{array}{l}\text { Sol. } 4 \text { c } 3 \mathrm{~W} \text {. } \\
\text { Theog. } 1267 \\
\text { Theog. } 88 \\
\text { Theog. } 74 \\
\text { Theog. } 698 \\
\text { Arch. } 185,6 \mathrm{~W} \text {. } \\
\text { Theog. } 196 \\
\text { Sol. } 34,3 \mathrm{~W} \text {. } \\
\text { Sol. } 11,6 \mathrm{~W} \text {. } \\
\text { Theog. } 121\end{array}$ & $\begin{array}{l}\text { C. } 48 \\
\text { C. } 45 \\
\text { A. } 8 \\
\text { C. } 41 \\
\text { C. } 42 \\
\text { C. } 36 \\
\text { E. } 70 \\
\text { C. } 51 \\
\text { A. } 10 \\
\text { A. } 17\end{array}$ & 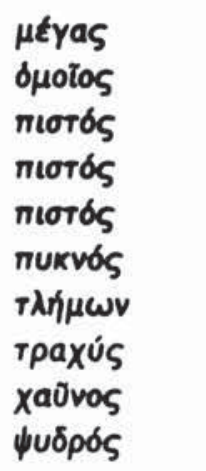 & $\begin{array}{l}\text { 'great', 'mighty'. } \\
\text { 'similar', 'alike'. } \\
\text { 'trustworthy', 'faithful'. } \\
\text { 'trustworthy', 'faithful'. } \\
\text { 'trustworthy', 'faithful'. } \\
\text { 'wise', 'clever'. } \\
\text { 'reckless', 'bold', 'daring'. } \\
\text { 'harsh', 'relentless'. } \\
\text { 'empty', 'frivolous'. } \\
\text { 'lying', 'false'. }\end{array}$ \\
\hline
\end{tabular}

